\title{
The regulation of pharmacists in Belgium and the Netherlands: in the public or private interest?
}

Citation for published version (APA):

Faure, M. G., \& Philipsen, N. J. (2002). The regulation of pharmacists in Belgium and the Netherlands: in the public or private interest? Journal of Consumer Policy, 25, 155-201.

https://doi.org/10.1023/A:1016092231002

Document status and date:

Published: 01/01/2002

DOI:

10.1023/A:1016092231002

Document Version:

Publisher's PDF, also known as Version of record

\section{Please check the document version of this publication:}

- A submitted manuscript is the version of the article upon submission and before peer-review. There can be important differences between the submitted version and the official published version of record.

People interested in the research are advised to contact the author for the final version of the publication, or visit the DOI to the publisher's website.

- The final author version and the galley proof are versions of the publication after peer review.

- The final published version features the final layout of the paper including the volume, issue and page numbers.

Link to publication

\footnotetext{
General rights rights.

- You may freely distribute the URL identifying the publication in the public portal. please follow below link for the End User Agreement:

www.umlib.nl/taverne-license

Take down policy

If you believe that this document breaches copyright please contact us at:

repository@maastrichtuniversity.nl

providing details and we will investigate your claim.
}

Copyright and moral rights for the publications made accessible in the public portal are retained by the authors and/or other copyright owners and it is a condition of accessing publications that users recognise and abide by the legal requirements associated with these

- Users may download and print one copy of any publication from the public portal for the purpose of private study or research.

- You may not further distribute the material or use it for any profit-making activity or commercial gain

If the publication is distributed under the terms of Article $25 \mathrm{fa}$ of the Dutch Copyright Act, indicated by the "Taverne" license above, 


\title{
N. J. Philipsen and M. G. Faure
}

\section{The Regulation of Pharmacists in Belgium and the Netherlands: In the Public or Private Interest?}

\begin{abstract}
The regulation of pharmacists in Belgium and the Netherlands is analysed in order to test the rent-seeking hypothesis put forward in the private interest literature. Both the self-regulation issued by the professional bodies and public regulations are examined. It appears that many regulations in both countries either restrict the entry into the profession or restrict competition within the profession. A qualitative comparative analysis of these regulations in both countries is presented as well as some empirical findings. The economic analysis and the empirical data seem to give some support to the rent-seeking hypothesis.
\end{abstract}

Many professions such as lawyers, architects, and doctors are subject to self-regulation by public professional bodies. This self-regulation may on the one hand restrict entry into the profession and limit competition within the profession, while on the other hand it may improve the quality of professional services. It merits a careful analysis whether the regulations by and of the professions can be considered to be "in the public interest" or predominantly serve private goals.

In this paper we select as a case study the market for (community) pharmacists. We present the first results from a comparative law and economics analysis of the regulation of pharmacists in two countries, viz., the Netherlands and Belgium. The central question in our research is the following: To what extent can the regulation of the pharmaceutical market in these countries be explained as a result of rent-seeking behaviour by pharmacists or other interest groups? In addition we are interested in the success of the rent seeking (if any). Therefore we would like to investigate whether differences in regulation between the two countries might - to some extent - explain the effectiveness of the rent seeking by pharmacists. Hence our paper fits both into the public choice tradition and into the (rather recent) comparative law and economics approach (for an extensive discussion of the public interest and private interest theories within this litera- 
ture, see, e.g., Ogus, 1994, Chs. 3 and 4; Posner, 1974, pp. 336-342; Van den Bergh, 1993, pp. 33-42).

The reason we have chosen Belgium and the Netherlands for our analysis is that, although it concerns two neighbouring countries, the regulation and the number of pharmacists are very different. Hence, it is particularly interesting to compare these two regimes within a comparative law and economics approach. It will allow us to examine whether the difference in the market structure of pharmacies in the two countries is related to the varying scope of the regulation. Moreover, it is interesting to focus on these two - rather different legal regimes since similar approaches towards the regulation of pharmacies can be found in other European legal systems as well. Hence, we expect that the findings have some relevance also outside the Belgian-Dutch context.

We should make it clear from the outset that the analysis in this paper is limited to certain aspects of the regulation of pharmacies. We do not examine price levels of pharmaceuticals in Belgium and the Netherlands, for example, and the influence of health insurers is only briefly addressed. These elements can be included in subsequent research.

The paper is structured as follows. First we provide an overview of the regulation of the pharmaceutical market in the Netherlands and Belgium. Both the self-regulation and the rules issued by public authorities that restrict (or may restrict) entry into or competition within the profession will be considered. Specifically, we look at the following potential restrictions of competition: professional ethics and rules of conduct issued by the professional body of pharmacists; registration and title protection; regulation of the establishment of new pharmacies; and rules on advertising and tariffs. To keep the paper within reasonable limits we will obviously have to focus on the most important features of these very extensive regulations. In the second part of the paper we will present the results from a qualitative comparative analysis of the regulation of pharmacists in the two countries, in the light of the economic approaches of the public and the private interest. We also give the first results from an empirical analysis of the number of pharmacists and the income of pharmacists in the Netherlands and Belgium. In the final section some concluding remarks and suggestions for further research are presented. 
THE REGULATION OF PHARMACISTS IN THE NETHERLANDS

Professional code and rules of conduct. The professional organization of pharmacists in the Netherlands is called the KNMP, which stands for the Royal Dutch Association for the Advancement of Pharmacy (Koninklijke Nederlandse Maatschappij ter bevordering der Pharmacie). The KNMP issued its new Professional Code and Rules of Conduct for Pharmacists in 1993. Over 90\% of all Dutch pharmacists are member of the KNMP, so the range of the self-regulation is very wide (KNMP, 1998, p. 6).

Apart from the Professional Code and Rules of Conduct, the KNMP also enacted the so-called Dutch Pharmacy Standards (Nederlandse Apotheek Norm) in 1996. The Dutch Pharmacy Standards have been enacted to work out the concept of "proper care" ("verantwoorde zorg") from the Care Institutions Quality Act ${ }^{1}$ and contain provisions on, e.g., the design of a pharmacy. Just like the Rules of Conduct, the Dutch Pharmacy Standards have no binding external force (they bind, in other words, only the members). However, these provisions can play a role in the medical disciplinary rules. Moreover, the Dutch Pharmacy Standards are to a large extent included in the individual contracts between pharmacists and health insurance companies. The most important provisions of the rules of conduct and the Dutch Pharmacy Standards will be discussed below, together with the legislation and the jurisprudence. Provisions that restrict competition between pharmacists will be emphasized.

\section{Registration and Title Protection}

The professional monopoly of a pharmacist. The professional monopoly of pharmacists is determined by the Drug Supply Act of 1958 (Wet op de Geneesmiddelenvoorziening) and by the Pharmaceutical Practice Decree of 1963 (Besluit Uitoefening Artsenijbereidkunst). Article 1 of the Drug Supply Act defines pharmaceutical practice as the compounding and the dispensing of medicines. Pharmaceutical practice is according to Article 2.1 reserved for pharmacists; and under specific conditions also to dispensing physicians, pharmacist's assistants, and the pharmaceutical industry and wholesalers. With respect to physicians who want to open a practice with a pharmacy, Article 6 provides that they may only practice pharmacy if a pharmacist has not been established either in the munic- 
ipality concerned or in the adjoining municipalities. Moreover, dispensing physicians are not allowed to prepare drugs themselves or to dispense drugs to patients other than those living in their work area. Limited competence to practice pharmacy is given to druggists and food companies, which means that they are permitted only to sell selfcare drugs at special counters. Thus, they are not qualified to deliver drugs on prescription. Given that only pharmacists may deliver drugs on prescription, they therefore have a professional monopoly in the extramural supply of prescribed drugs.

Registration. Before a pharmacist is allowed to practice pharmacy in the Netherlands, he or she must be registered with the regional Health Inspectorate (regionale Inspectie voor de Gezondheidszorg), in accordance with Article 14 of the Drug Supply Act. A number of requirements for registration are laid down in the Pharmaceutical Practice Decree, among them the requirements for the applicant to submit a pharmacy diploma and a statement of the property (Article 2). Once registered, a pharmacist or dispensing physician may only practice pharmacy in one pharmacy, according to Article 19 of the Drug Supply Act.

The Pharmaceutical Practice Decree also contains a prohibition for the pharmacist to enter into any kind of agreement with respect to the public dispensing of medicines with physicians, dentists, or midwives (Article 18). In 1999 a provision, which restricted the entry of pharmacists to the market, was repealed from this decree, namely Article $15 .^{2}$ That article provided that pharmacists were not allowed to be employed by non-pharmacists. Since the repeal of Article 15, it has become possible for qualified pharmacists to work in, e.g., a chemist's chain.

Title protection. In November 1997 the Individual Health Care Professions Act (Wet op de Beroepen in de Individuele Gezondheidszorg), hereafter Professions Act, came into force. ${ }^{3}$ For a number of health care professions the ban on the unqualified practice of the profession, which existed in the past, has been substituted by a system of registration combined with title protection and partial protection of the profession through a number of so-called reserved operations ("voorbehouden handelingen"). However, for pharmacists no reserved operations have been defined in the Professions Act. For them the protection of the professional monopoly supplied by the Drug 
Supply Act still applies. New is that the formal use of the title "pharmacist" is now reserved to those who are registered in the register of the Professions Act. This register is managed by the Minister of Health, Welfare and Sport.

Article 22 states how the title "pharmacist" (and thus the entry into the register of the Professions Act) can be obtained. Required is the possession of a legally obtained certificate. The unqualified use of the title "pharmacist" or a similar title is subject to punishment. ${ }^{4}$ In article 23 of the Professions Act the area of expertise of pharmacists is defined to be "the performing of acts in the area of pharmaceutical practice." To be able to actually practice their profession, pharmacists registered with the Professions Act still have to apply to the regional Health Inspectorate, as described earlier in this section. Registration with the Health Inspectorate will be refused if the applicant does not have the title "pharmacist."

\section{The Establishment of Pharmacies}

The establishment policy of the KNMP. In the period between 1975 and 1987 the pharmacists' association's private establishment policy applied: the KNMP Establishment Policy Decree (Besluit Vestigingsbeleid KNMP). Members had to receive the permission from the executive board of the KNMP if they wanted to establish or relocate a pharmacy. These rules were based on the idea that a proper quality of pharmaceutical aid can only be obtained if the financial foundation of a pharmacy is financially sound; and that for this a market of at least 8000 patients per pharmacy is required. ${ }^{5}$ But the KNMP has never been able to prevent non-members from establishing themselves. Suspension and the disqualification from practice can never be private law disciplinary rules; these are after all matters pertaining to public law. However, the KNMP can punish with, e.g., a warning, a fine, a suspension from the membership of the KNMP, or the deprivation of the right of being member of a KNMP board or committee (Leenen, 1991, pp. 261-262).

In theory it is possible to establish a pharmacy without being a member of the KNMP. This is, however, very difficult in practice for reasons we will explain below. In the case law of the early 1980s, the court repeatedly determined in civil law cases that non-members are not bound by a private law establishment policy. ${ }^{6}$ The objection that the establishment policy of the KNMP was a generally acknowl- 
edged code of conduct might have been somewhat true, but this still cannot make a private rule legally binding. When the number of "black establishments" increased in the 1980s, the KNMP therefore changed its establishment policy. From 1987 onwards an advisory establishment policy without sanctions applies, called the Guidelines concerning the KNMP advisory establishment policy (Richtlijnen betreffende het vestigingsadviesbeleid KNMP).

According to these guidelines, the KNMP gives advice about the establishment, relocation, and closure of pharmacies, at every member's request. Also non-members and interested third parties may ask the KNMP for advice. Besides, the Guidelines even allow the KNMP to advise on certain issues without being asked. Article 4 of the Guidelines provides the criterion for positive advice as to establishment or relocation: "Within an acceptable time the new or relocated pharmacy must be able to grow to a size that guarantees the foundation for a qualitatively good practice of the profession by the pharmacist(s). In addition, the conditions for good practice by the adjacent pharmacies have to be maintained. As a basis the Minimum Establishment Standard for Pharmacies (Minimum KNMPVestigingsnorm voor Apotheken) shall apply." In a commentary to Article 4, it is stated that the above includes that pharmacies have to be reasonably far apart and that newcomers may only inflict damage upon established pharmacists as long as this damage is not "unreasonable." The KNMP strives for the realization of viable pharmacies. The above-mentioned Minimum Establishment Standard for Pharmacies serves as a guideline for assessing the economic feasibility - or the viability - of a pharmacy.

In the assessment, inter alia the following factors are considered: the expected number of prescriptions, the number of patients, the turnover, the number of physicians in the area, and infrastructural characteristics. To determine the economic feasibility, first the gross profit at the expected number of prescriptions is calculated. From this gross profit the costs of practice (among them personnel and housing costs) and the investment and financing costs are subtracted, while the writing-offs are being considered as well. Because the gross profit has been related to the prescription volume since January 1988, the establishment standard of the KNMP is also defined in the number of prescriptions. The standard for economic feasibility of a pharmacy lies at a structural (minimum) number of prescriptions of 40,000 per year. No difference is made between prescribed and non-prescribed drugs 
and medical devices. ${ }^{7}$ The estimate is flexible: The required minimum for economic feasibility is brought up to date by the KNMP if the Health Charges Board (CTG) makes an adjustment in the tariffs. If important market developments are observed by the Foundation for Pharmaceutical Statistics (Stichting Farmaceutische Kengetallen), those will also be included in the estimate. Dependent on the geographical position of the newcomer, additional preconditions apply in the judgement of economic feasibility, because a distinction is made between establishment in a rural area with a dispensing physician, establishment in an urbanised area, and establishment in a demarcated new housing estate.

Contracts between pharmacists and health insurers. Although the advices of the KNMP are not compulsory, the advisory establishment rules of the KNMP are often included in some way in the contracts between health insurers and pharmacists. Market division is obviously prohibited by the Dutch Competition Act, and yet the health insurers draw up agreements with pharmacists or their regional associations, which have names like "paper concerning the capacity and the distribution of pharmacists." It appears from the case law that these agreements often contain about the same requirements as the old KNMP Establishment Policy Decree. In one of the cases from the rather extensive case law in the field of sickness funds, it was provided in the paper of the sickness fund in question that a pharmacist's sphere of activity ought to be larger than 7,500 patients and that in principle contracts would only be made with a pharmacistowner-administrator. ${ }^{8}$ This is a clear example of market division, yet the Court decided in this case that there were plausible grounds for this: a well-considered distribution of care, to be provided by financially viable pharmacies that are managed rightly. Actually, the condition that contracts will only be made with a pharmacist-owneradministrator is also included in the Dutch Pharmacy Standards of the KNMP: Article 8.1 holds that a pharmacy needs to be governed by a registered community pharmacist. In the jurisprudence, similar cases concerning contracts between health insurers and pharmacists can be found. However, the Dutch Competition Authority (the NMa), which was founded in January 1998 to look after the new Dutch Competition Act, seems to be stricter with respect to violations of the market division prohibition. 
Summary. It can be concluded that in practice it is very difficult to start a new pharmacy. It is hard for a recently established pharmacist to make contracts with health insurers in an area that does not meet the standards enacted by the KNMP. Non-members effectively have no chance of entry into the market for the simple reason that their medicines will not be reimbursed by the health insurance (which is obviously disadvantageous for customers) unless they succeed in concluding contracts with these health insurers. For pharmacists who are members of the KNMP it is practically impossible to withdraw from the advisory establishment policy anyhow: Article 2.13 of the Professional Code and Rules of Conduct provides that advice by an authorized KNMP body has to be considered as important.

\section{Advertising and Design of the Pharmacy}

Advertising for pharmacies. Advertising by pharmacists is not regulated by law, as opposed to the advertising of drugs. In the Professional Code and Rules of Conduct of the KNMP are two articles on this subject. Article 2.16 provides the following: "A community pharmacist is not allowed to approach patients directly and individually, if these patients are not his own clients. Also he is not allowed to compare himself with colleagues who are mentioned by name or who are distinctly indicated." The other restriction is mentioned in Article 2.23: "Improper competition is prohibited. As such are always considered: (a) taking over patients/clients during duty or observation; (b) actively attracting staff from a neighbouring colleague; (c) in any way affecting the patients' free choice of pharmacy." By the end of 1997 the Economic Competition Committee (Commissie Economische Mededinging) had already advised the Minister of Economic Affairs not to give an exemption from Article 2.16, but the Committee had approved of Article 2.23a because of the importance of a well-functioning evening/weekend observance regulation. ${ }^{9}$ Nevertheless, the KNMP rules of conduct still have not been adapted accordingly.

It can be concluded that Dutch pharmacists face many difficulties if they want to show their qualities to patients. Competition in the quality of supplied services seems only to be possible by providing extra services to customers, such as home delivery of medicines, or by offering a broad range of medical supplies and other products that can be obtained without prescription. 
Design of the pharmacy. The original Articles 32 and 34-36 of the Pharmaceutical Practice Decree contained some requirements that pharmacies had to comply with regarding design and accessibility of the building. These articles were repealed in January 1996, because they were considered to have "an adverse effect on the efficiency of the functioning of pharmacies." ${ }^{10}$ However, most of these provisions are now included in the Dutch Pharmacy Standards. Most important are the following three: a pharmacist must be able to deliver every sensible prescription; a pharmacy must have a separate room for magistral preparation of medicines; and the pharmacy must be open for at least 9 hours between $8 \mathrm{AM}$ and $6 \mathrm{PM}$ and for at least 45 hours a week.

\section{Tariffs}

The price of WTG drugs. In the Netherlands, drugs are divided into two categories: WTG and non-WTG. WTG drugs are drugs that are available only at the pharmacy and which therefore fall under the Health Care Charges Act (Wet Tarieven Gezondheidszorg, WTG). Non-WTG drugs may also be supplied in outlets other than pharmacies, such as the chemist or sometimes even a supermarket. If supplied on prescription at the pharmacy, non-WTG drugs may still be covered by the health insurance, but only under specific conditions. Of all drugs supplied by community pharmacies on prescription, $85.1 \%$ were WTG drugs in 1998 (SFK, 1999, p. 32).

The fee pharmacists receive for supplying WTG drugs, called the fixed fee, is not related to the cost of the product. On the contrary, the fee is fixed per prescription and does not depend on whether the medicine costs $€ 5$ or $€ 50$. The fee also does not depend on the prescribed amount. The result is that in the Netherlands tariffs for WTG drugs do not or just barely differ between pharmacies. The purchase fee, the refund paid by insurers to pharmacists for the dispension of drugs in the pharmacy, is determined by a reimbursement list in the so-called taxe of Z-index. Z-index belongs to the pharmacists' association KNMP. The taxe is a list of all drugs registered in the Netherlands and is published every month on the basis of the CTG $^{11}$ tariff orders. The CTG tariff orders include the fixed fee per prescription and the amounts that pharmacists may charge to compensate their purchase costs. In practice this means that the purchase costs of drugs may be passed on fully by the pharmacist (MDW, 1999, 
p. 67). The taxe of Z-index is the only reimbursement list that satisfies the tariff orders of the CTG.

In the taxe the prices as set by the producers are entered. Because the principle "pharmacy purchase price $=$ pharmacy retail price" is operated, the producer determines the final retail price of the drug, thereby taking into account the Drug Prices Act (Wet Geneesmiddelenprijzen) and the Drug Reimbursement System (Geneesmiddelenvergoedingssysteem). ${ }^{12}$ Once a drug has been included in the taxe, the only room left for the drug producer to compete by means of the price level is by using the space between the cost price and the pharmacy purchase price as fixed in the taxe. This space is used by the producers to provide bonuses and discounts to pharmacists in order to persuade them to provide their drugs instead of those of competitors (MinVWS, 1999 b, p. 28) The patient or insurer does not benefit from these practices. Moreover, insurers are allowed to deviate from the taxe prices with the reimbursements to pharmacists, but they hardly do this because of the high administrative troubles attached to a diversity of prices. In the current situation they only have to deal with one price per drug. By the end of the 1990s the government gave the fight against bonuses and discounts a prominent place in its drug policy. Since then, pharmacists have been obliged by the government to pass on some of their rebates by a decrease in the reimbursement prices of drugs that they may charge (MinVWS, 1999 b, p. 49). This legally determined deduction of the reimbursement price is called "claw back."

The pharmacist's fee. What is now the fee a pharmacist receives for his services of drug dispensing, customer advice, and looking after medication surveillance? For every dispensed drug on prescription he or she receives the fixed fee (receptregelvergoeding), which in 2001 was $12.50 \mathrm{NLG}$ ( $€ 5.67$ ), irrespective of the price or the quantity of the drug. The fixed fee is updated each year by the CTG. Hereby the CTG looks especially at developments in the number of dispensed WTG drugs per year. Also there is a substitution measure that makes up part of the pharmacist's fee, albeit relatively small compared to the fixed fee. The substitution measure fits in with the idea that a prescriber (e.g., a physician or specialist) in principle has to prescribe under the substance name and not under the brand name. This so-called incentive measure entails that a pharmacist is allowed to keep $1 / 3$ of the price difference between a proprietary drug and 
an equivalent parallel-imported or generic drug. The final saving for the insurer is then twice as high as the incentive revenue of the pharmacist. However, the price differences between branded and generic drugs are becoming smaller and smaller by the oppressive effect the Drug Prices Act and the Drug Reimbursement System exert on the price level. The possibilities for parallel import therefore decrease drastically as well. In 1999 it became clear that the government intended to incorporate the average incentive revenue per prescribed WTG drug of $0.40 \mathrm{NLG}(€ 0.18)$ in the fixed fee. ${ }^{13}$ Pharmacists are then more or less obliged to obtain a minimum amount of substitution. The fixed fee and the incentive measure came into force on January 1, 1988 (RVZ, 1998, p. 96).

The KNMP claims that the fixed fee has not been adapted sufficiently to the rising pharmacy practice and staff costs, while in addition the revenues from the incentive measure have decreased as a result of the levelling of prices of proprietary and generic drugs. The deficits in the pharmacy budget, which according to many pharmacists have arisen, have been counterbalanced by bonuses and discounts from industry and wholesalers. After all, price competition has already been made virtually impossible as a result of all the government interference.

To the preceding discussion must be added, for the sake of completeness, that a pharmacist also receives revenues from the sale of non-WTG drugs and medical devices. The average profit margin on these products lies between 20 and 30\% (KNMP, 1998, p. 41). Just like the taxe for WTG drugs, the retail and purchase prices of these products are included in a list that is issued monthly by the KNMP. Contrary to the case of WTG drugs, there is some price competition between pharmacies in this field. However, since the sale of WTG drugs makes up (by far) the largest part of the turnover in pharmacies, it concerns relatively small amounts of money. ${ }^{14}$ Moreover, in calculating the fixed fee the CTG takes the average revenues pharmacists obtain from trade activities other than the sale of WTG drugs into account as well.

Summary. The conclusion can be kept short. It appears that the possibilities for pharmacists to compete do not lie in their price policies. Quite to the contrary, the government regulates the whole market, with the exception of the relatively much lower revenues of pharmacists from other trade activities than the sale of WTG drugs. 
THE REGULATION OF PHARMACISTS IN BELGIUM

\section{Professional Code and Rules of Conduct}

In Belgium pharmacists are organised in the Order of Pharmacists (Orde der Apothekers), which was called into being by an Act from 1941. This Act was replaced in 1967 by the Royal Decree no 80 concerning the Order of Pharmacists (Koninklijk Besluit nr. 80 van 10 november 1967 betreffende de Orde der Apothekers), which since then has contained the most important provisions related to this Order. ${ }^{15}$ Three years later a Royal Decree was formulated that specifies the organisation and the functioning of the boards of the Order. ${ }^{16}$ Next to the national board of the Order of Pharmacists there are ten provincial boards, as well as a Dutch-speaking and a French-speaking Board of Appeal. In a case from 1993 the tasks and competences of the Order were described as follows: "The Order of Physicians and the Order of Pharmacists are public institutions that have been founded by law and who have competences, which are enforced under the supervision imposed by that law. They have as their duty to watch over the respect of the ethical rules, as well as the compliance with the honour, the discretion, the decency and the dignity of the Order members. They group in a compulsory way all those that practice the profession of physician or pharmacist. ${ }^{, 17}$

The so-called professional deontology, issued by the Order of Pharmacists, provides the ethical rules about the practice of the pharmacist's profession. Formally, these professional rules have no legal binding force, no more than the Dutch case of the professional code and rules of conduct issued by the KNMP. The King of Belgium does have the possibility to grant binding force to these rules, but until now this has never happened. The professional deontology was formulated some decades ago by the national board of the Order and has barely changed in the course of time. The national board of the Order of Pharmacists can also give advice about matters that are of interest to pharmacists. Again, this kind of advice has no legally binding force and therefore cannot contain obligations. Should such an advice still carry obligations or prohibitions, then it may be subjected to an annulment by the Council of State (Raad van State) (Balthazar, 1994, p. 114). The most important duties of the provincial boards are approving, postponing, or refusing entries into the 
register of pharmacists (which is kept up to date on the provincial level), watching over the compliance with the professional rules in the province, and taking disciplinary measures. Possible sanctions that can be imposed by the provincial boards of the Order are the following: warning, censure, reprimand, the suspension of professional practice for at most two years, and elimination from the register of the Order. ${ }^{18}$

Next to the Order of Pharmacists there is a federation that groups all pharmacists on a national level: the Belgian Pharmacists Association (Algemene Pharmaceutische Bond), hereafter APB. The APB offers pharmacists and the pharmaceutical sector many services, such as a drugs data base and a Documentation office, and publishes several magazines.

In the following sections the effects of the Belgian self-regulation and public regulation on the functioning of the market for pharmaceutical services will be described.

\section{Registration and Title Protection}

The professional monopoly of the pharmacists. The protection of the professional monopoly of community pharmacists (officinaapothekers) is laid down in the Royal Decree no 78 from 1967 concerning the practice of medicine, nursing, the paramedical professions and the medical committees. ${ }^{19}$ Article $4 \S 1$ of this decree holds the following: "No one is allowed to practice pharmacy who does not have the legal pharmacist's diploma, obtained according to the legislation on the assignation of academic degrees and the programme of the university exams, unless that person is exempted from this by law." Dispensing drugs, even if this happens free of charge, is not allowed if this is done "on a common basis" by someone who does not meet this criterion. It is also prohibited for non-qualified persons to prepare drugs, to offer drugs for sale, or to sell them in the retail trade. The operations reserved for pharmacists are thus listed indirectly here. ${ }^{20}$ According to Article $4 \S 2$, under specified conditions physicians, dentists, and veterinary surgeons have a limited competence to dispense drugs too.

In Belgium, for the dispensing of registered drugs a doctor's prescription is required, like in the Netherlands. ${ }^{21}$ However, substitution of branded drugs by generic drugs is not allowed for pharmacists (see below). 
Registration. A pharmacist who has obtained a diploma is not immediately permitted to practice pharmacy. He first has to have his title formally approved by the Medical Commission (Geneeskundige Commissie $)^{22}$ of the province where he is planning to establish himself and he has to register with the Order of Pharmacists. It is not allowed to practice medicine and pharmacy at the same time, not even for holders of both diplomas. Exceptions have been made for dispensing physicians. The criterion is comparable to the Dutch one: In a region, a dispensing physician can only establish himself if the geographical distribution of pharmacies makes it impossible to meet the requirements of public health. Moreover, physicians who are allowed to dispense drugs are not allowed to have a public (community) pharmacy. If a pharmacy is to be established in a region with a dispensing physician, the physician in question has a two year term to do away with his drug depot. Account is taken of possible mitigating circumstances. ${ }^{23}$ However, in practice these rules are not relevant anymore; there are almost no dispensing physicians left in Belgium because of the large number of community pharmacies.

From this it may be concluded that in Belgium the professional monopoly of the pharmacist is protected by the government. The practice of pharmacy is subject to a double registration procedure and the tasks of a pharmacist are clearly, be it indirectly, enumerated. The King, viz., the government, has a large say in the practice of the pharmacists' profession.

\section{Establishment of Pharmacies}

The rules for the establishment of pharmacies are formally prescribed in Belgium. Already in 1967 the basis of these rules was formulated in the Royal Decree no 78. Article $4 \S 3$ of this decree states: "For the opening, transferring or merging of community pharmacies a prior permit is required, granted to one natural or one legal person making the application. [. . .] The King determines [.. .] the criteria intended to organise a distribution of the pharmacies." These criteria have been worked out in two important decrees: the Royal Decree of 25-9-1974 concerning the opening, transfer and merger of pharmacies open to the public, ${ }^{24}$ and the Royal Decree of 13-4-1977 settling the rules that permit to fix the value of the transfer of pharmacies and to supervise this transfer. ${ }^{25}$ 
Supervision of the establishment of pharmacies. The Belgian establishment law can be characterized as an administrative-legal system of permissions supported by a system of criminal injunction and sanctions (Nys, 1981-1982, p. 2576). Permissions are given by the Minister of Health and advice is given by an establishment committee. The objective of the establishment policy is stimulating public health by "restricting the number of pharmacies to a maximum for every municipality" in order to realize a good distribution of pharmacies, according to Article $1 \S 1$ of the Royal Decree of 1974. The establishment of new pharmacies is made very difficult by the strict criteria that are employed. The maximum number of pharmacies in every municipality depends on the population figure of the municipality concerned (Article 1 §). Depending on whether the population of the municipality is at least 30,000 , between 7,500 and 30,000 , or less than 7,500 , the number of pharmacies may not be higher than the quotient that is the result from the number of inhabitants divided by 3,000 , 2,500 , and 2,000, respectively. Next to that, $\$ 3$ contains a series of distance criteria, which allow a deviation from the population criteria. That is, the establishment of a pharmacy will also be permitted if the pharmacy that lies closest to the planned pharmacy is located 1, 3 , or 5 kilometres away and covers the needs of 2,500, 2,000, or 1,500 inhabitants, respectively. In practice, the criterion 5 kilometres $-1,500$ inhabitants is no longer relevant (Demeester, 1990, p. 118).

The Belgian government feared that the "oversupply" of pharmacies would lead to too much competition and less service to patients. That is why in 1994 the government supplemented the establishment rules from the Royal Decree of 1974 with a moratorium. ${ }^{26}$ For a period of five years, lasting until 8 December, 1999, it was not allowed to open new pharmacies; only a better distribution of pharmacies in certain areas was still permitted. This moratorium was renewed in 1999 for a period of as much as ten years. At the same time a registration procedure for all existing pharmacies was adopted, in order to supervise the moratorium more effectively. ${ }^{27}$

Supervision of the takeover price of pharmacies. The Royal Decree of 13-4-1977 imposes restraints on the takeover price of a pharmacy. The implementation of this decree is in the hands of the Minister of Health. Article $1 \S 1$ dictates that the value of the transfer of a community pharmacy may not be higher than the sum of three elements: " $1{ }^{\circ}$ the furniture and the equipment, estimated by a registered expert; 
$2^{\circ}$ the stock of products belonging to the pharmacist's profession, estimated by a registered expert; $3^{\circ} 150 \mathrm{pc}$ of the average of the gross profits which have been gained in the course of at most the five taxable periods preceding that of the transfer." Yet the limits of the takeover prices are quite easy to circumvent because the price of the building is free. After all, in the Royal Decree of 13-4-1977 no account has been taken of the price of real estate.

Concluding, the same problem exists in Belgium as in the Netherlands, namely that it is extremely difficult for beginning pharmacists to capture a place in the market. This is not only a result of high takeover prices, but also of the tightening of the establishment act in the form of the moratorium that has been included into the Royal decree of 25-9-1974.

\section{Exercise of the Profession}

Advertising for pharmacies. In Belgium, the advertising by individual pharmacists for their practices is supervised by the Order of Pharmacists on the basis of their professional rules. The second deontological (i.e., professional) rule of the Order of Pharmacists, formulated in 1951, warns against excessive commercialization of the profession. It states that, for pharmacists, it is "not deontological" to provide, encourage, or tolerate any kind of publicity for the benefit of their practice. The Order wants to prevent that the honour and dignity of the pharmacist's profession is harmed by advertising. The third professional rule, which was formulated in 1955 and which contains provisions with regard to unfair competition between pharmacists, gives a more detailed explanation of this. Article 3.4 of this rule reads as follows: "A pharmacist is not allowed to advertise in any form, directly or indirectly, for the benefit of his practice. For instance by prospectuses, circular letters, by a special typographical style or special announcements in the phone books, press, radio, cinema, gifts, travellers, the promise of all sorts of benefits like refunds, discounts, bonuses etc. . ..". Finally, Article 1c of the same professional rule prohibits a pharmacist to "make mention of the soundness of his products and of the value of his preparations, with the view of making it seem as if his colleagues make no claim to this quality."

However, in early 1999 a very important decision was taken by the Court of Cassation which considerably weakened this supervisory function of the Order. ${ }^{28}$ In the decision in question, the Court 
of Cassation nullified a decision of the Board of Appeal of the Order of Pharmacists, in which a disciplinary punishment was imposed on a pharmacist who distributed carrier bags with the logo of her pharmacy on them. The Court of Cassation decided that the Order of Pharmacists is an entrepreneurial association and as such falls under competition legislation. ${ }^{29}$ Being an entrepreneurial association, the Order is not allowed to impose obligations that restrict, prevent, or distort competition. It is allowed to examine whether the advertising used is reconcilable with the professional rules of the pharmacist. Only if by advertising the honour or dignity of the profession is seriously endangered, such advertising may be prohibited. Thus, in principle pharmacists are allowed to advertise for their stores. ${ }^{30}$ With this decision the Belgian Court of Cassation follows the European trend, ensuing from the European competition rules. On 23 April, 1999, the European Commission already decided that the European competition rules with respect to advertising are applicable to the professions as well. Moreover, this decision not only brings the Belgian disciplinary procedures in line with the provisions in European law, but also with the state of affairs in other European countries, among them the Netherlands. ${ }^{31}$ In the Netherlands, incidentally, a similar case occurred already in 1998 . The Dutch competition authority NMa determined on 27 August, 1998, that the KNMvD, the association for veterinary surgeons, is an entrepreneurial association falling under the Dutch Competition Act. ${ }^{32}$

Design of the pharmacy. In 1965 the Order of Pharmacists issued a professional rule that has an effect on the design of pharmacies. In its sixth professional rule concerning the pharmacist's publicity, some instructions regarding the design of the pharmacy and the shop-window (it is for instance prohibited to "display therapeutic instructions or recommendations in any way on behalf of the public") and a ban on provocative neon signs have been formulated.

\section{Tariffs}

The price of drugs. In Belgium the price structure and the distribution margins in the market for drugs are determined by law, just as in the Netherlands. The drug prices are determined by the Ministry of Economic Affairs. Whenever an agreement about the price is reached with the drug producer, this price is laid down legally. 
Moreover, the Minister of Economic Affairs first has to consider a recommendation for the prices by the Drug Board (Geneesmiddelencommissie). This Drug Board, which is under the supervision of the Ministry of Health, also has responsibility for the assessment of registration requests for drugs. ${ }^{33}$ If it concerns drugs that are eligible for reimbursement by the mutualiteiten (the Belgian sickness funds), the price is assessed by the technical board for pharmaceutical specialities of the RIZIV, the National Institute for Health Care and Invalidity Insurance, as well. To qualify for reimbursement by the mutualiteiten, a drug producer has to file an application for acceptance with the RIZIV, simultaneously with an application for recognition of the price at the Ministry of Economic Affairs. Before a drug will be reimbursed by the health insurers, it has to comply with certain criteria stated in the Royal Decree of 2-9-1980 determining the conditions under which the mandatory health care-and invalidity insurance will be prepared to bear the costs of the pharmaceutical specialities and of equal products. ${ }^{34}$ They include pharmacotherapeutical criteria, society's interest in the drug, and price criteria. ${ }^{35}$ Depending on a number of criteria, drugs will be assigned to one out of six groups that correspond to different reimbursement rules, stated in Article 15.

Unlike the situation in the Netherlands, substitution of generic drugs for (more expensive) proprietary drugs occurs very rarely in Belgium. At the beginning of 2001, the percentage of generic drugs in Belgium was only $1 \%$ of all drugs, while in the Netherlands this percentage was about $30 \%$ (measured in percentage of turnover). Part of this can be explained by examining the stringent rules with regard to substitution of proprietary drugs. Article 11 of the Royal Decree no 78, which was added to the text of the decree in 1993 but still has not come into force for political reasons, provides: "The King determines, by a decree consulted in the Council of Ministers, the provisos and the implementing measures according to which the pharmacist is allowed to substitute a prescribed pharmaceutical speciality by another, under the conditions that the active components of the substitute are the same and that the prescriber does not explicitly resist against such a substitution and that the price for the patient is cheaper". Unfortunately Belgian physicians still precribe many branded drugs and they generally are not so favourably disposed towards substitution by pharmacists. Moreover, the pharmacists' association APB admits that pharmacists do not have an incentive to 
substitute, as long as they will earn less on selling a generic medicine than on selling a branded drug. ${ }^{36}$

Reimbursement for the pharmacist. Besides the fact that a pharmacist has few possibilities to substitute drugs, the margins on drug sale have been fixed, both for wholesalers and for pharmacists (PriceWaterhouseCoopers, 1999, p. 15). Pharmacists receive a margin of 31 percent on the sale of drugs, up to a ceiling of $300 \mathrm{BEF}$ (€ 7.44) for every packaging. Because more and more expensive drugs and drugs in large packagings are coming onto the market, margin erosion occurs: The pharmacists' association APB claims that the real profit margin is only $26.5 \%$ per prescription. The explanation for this is that as much as $40 \%$ of the sale of drugs is sold at the ceiling price or above because of the ever increasing drug prices. The APB fears that it will become more and more difficult for pharmacists to keep expensive drugs in stock. Therefore the pharmacists' association asks for a marginal margin on the more expensive products. ${ }^{37}$ However, if the price structure of medicines in different countries - divided into the margin for the producer, wholesaler, pharmacist, and government (VAT) - is compared, then it seems that the margin for pharmacists in Belgium lies at an average level. ${ }^{38}$

Summary. Summarising, it may be stated that competition between pharmacists or between wholesalers in Belgium has no influence at all on the tariffs, given that prices and margins are legally determined. The pharmacists' associations, like the umbrella association APB and the Order of Pharmacists, only function as bargaining partners and advisory bodies here.

\section{A COMPARATIVE ECONOMIC ANALYSIS OF REGULATION IN THE NETHERLANDS AND BELGIUM}

For the analysis of these different and complex Belgian and Dutch institutions one could choose various approaches. It seems first of all interesting to highlight a few similarities and differences concerning the regulation of pharmacists in the two countries. Then we will analyse to what extent these complex regulations can be considered as serving a public interest goal or a private interest goal. In the final section we will present some quantitative data to illustrate the 
extent to which pharmacists in both countries can be considered as successful rent seekers.

\section{Differences and Similarities in Regulation}

A brief look at the regulation of the pharmaceutical profession in the Netherlands and in Belgium shows that there are many similarities. While neither of the countries has a numerus clausus for the admission to the study of pharmaceutics, both countries do regulate the entry into the profession by registration procedures and rules with respect to the establishment of new pharmacies. They have in common that the government protects the professional monopoly of the pharmacy (the definition of which is about the same in both countries). Moreover, in the Netherlands as well as in Belgium pharmacists have to be registered with a regional medical commission, although in Belgium pharmacists also have to be registered with the Order of Pharmacists. In the Netherlands the second register for pharmacists is the public register that protects the title of "pharmacist." This may constitute a relatively small difference in regulation. However, a major difference is that in Belgium the establishment policy with respect to new pharmacies - including the regulation of takeover prices - is completely regulated by royal decrees, as opposed to the Dutch advisory establishment policy of the pharmacists' association KNMP. In general it appears that the Order of Pharmacists in Belgium, which has been called into being by law, has tasks that differ from those of the Dutch KNMP, the duties of which are not legally prescribed. However, in both countries the degree of self-regulation is impressive.

In the Netherlands and in Belgium the self-regulatory body of pharmacists prohibits its members to make the pharmaceutical market transparent for consumers by means of advertising for the individual pharmacy. Also the rules concerning the design of the pharmacy and the exercise of the profession can be found in the self-regulation rules issued by both the KNMP and the Order of Pharmacists. There are of course some differences in the content of these rules, but the overall tendency is the same in both countries. This kind of self-regulation is obviously restricting competition and inhibits a differentiation of services. However, this self-regulation of advertising and exercise of the profession has come under attack recently in case law, especially in Belgium, but also in the Netherlands.

In the field of drug pricing policy and tariffs there appear to be 
many similarities too. Both in the Netherlands and in Belgium pharmacists do not have any influence on prices of drugs and on the tariffs they may ask for their services. However, there are differences in the pharmacist's fee: The receptregelvergoeding in the Netherlands is a fixed amount, while the pharmacist's margin in Belgium amounts to a percentage of the drug price. Furthermore, in Belgium there is no incentive measure directed at the prescription of cheaper products. On the contrary, a Belgium pharmacist might sooner be tempted to substitute more expensive drugs for cheaper ones. Legal provisions prohibit this, but the supervision of this is not always easy. Also, in both countries health care insurers seem to have an important influence on the price of drugs or on the fee for the pharmacist, and thus indirectly on the pharmacist's income.

\section{A Public Interest Analysis of the Regulation of the Dutch and Belgian Pharmaceutical Markets}

We will now take a brief look at some of the regulations examining the extent to which they can be considered as serving a public interest and a private interest goal, respectively. Of course, regulations do not necessarily exclusively serve either a private or a public interest goal; a combination of goals is possible. We will therefore ask, rather, to what extent the regulations serve a public or a private interest goal.

\section{The Public Interest Argument: A Reminder}

The public interest approach to regulation gives a number of grounds for regulatory intervention in a market, grounds which have in common that they are derived from the perceived shortcomings of the market system itself to deal with certain problems preventing an economically efficient outcome in a market. ${ }^{39}$ Four kinds of market failure are generally discerned: (1) market power; (2) information problems, e.g., information asymmetry between supplier and buyer resulting in adverse selection or moral hazard; (3) external effects; and (4) the presence of public goods. Regarding the pharmaceutical market especially the information asymmetry argument seems to apply, although there may also be external effects in that market, for example as a result of bad medication guidance or wrong drug advice. There seems to be a clear informational asymmetry between pharmacists and 
patients, because consumers cannot be assumed to have adequate information on the quality of the services provided. The services provided by pharmacists can be called experience goods (the quality of which can only be determined after having consumed or used it) or maybe even trust (or credence) goods (the quality of which cannot be assessed correctly even after consumption of the good) (Nelson, 1970; Tirole, 1992, p. 106). Without regulation there will be adverse selection in the quality of pharmaceutical services: Bad professionals (quacks) will drive those who provide high quality services out of the market (Akerlof, 1970). Therefore informational asymmetry and external effects may provide a public interest justification for regulatory intervention aimed at guaranteeing a reasonable quality of pharmaceutical services.

Regulatory intervention differs in the extent to which it intervenes in a market. In some markets a simple information regulation (in the form of, e.g., mandatory information disclosure or a prohibition of misleading advertising) may be sufficient to solve market failure. In other markets a stronger regulation may be needed, such as prescribed quality standards or certification and licensing. However, the danger exists that a regulatory solution to market failure causes misallocations in other sections of the economy or generates transaction costs that are bigger than the efficiency gains from the regulation. Therefore regulatory failure always has to be compared with market failure: Is the cure (regulation) maybe worse than the disease (market failure)? In the following section we will therefore discuss whether the tightly regulated Dutch and Belgian pharmaceutical markets really serve the public interest.

Analysis. Pharmacists in the Netherlands and Belgium have a professional monopoly in the dispensing of prescribed medicines to patients. Moreover, in the Netherlands the title of pharmacist is protected by law, so that consumers can only hand in their prescriptions at a registered pharmacist who has a legally obtained diploma. In Belgium pharmacists have to have their title formally approved before entry into the market. Because pharmaceutical services are experience goods $^{40}$ (or even trust goods) in a market characterized by information asymmetry between pharmacist and patient, some regulation is necessary to prevent quality deterioration of the kind described by Akerlof (1970). However, the question arises whether this regulation should take the form of title protection, as is the case in the 
Netherlands and in Belgium. There is a double registration procedure (regional and national) in both countries. The regional registration is said to be necessary to keep the administration of the number of pharmacists (in all categories) up to date. The fundamental question that remains unanswered is whether a far-reaching regulatory instrument such as title protection is necessary to reach the public interest goal of protecting public health. Other instruments that already partially exist (such as ex ante control of the quality of pharmaceutical products) could also reach that goal to some extent, without the negative effects as far as the restriction of competition is concerned. Indeed, an additional problem is that the specific services of the pharmacist (such as giving advice) might warrant regulation, but this is less the case for the sale of prescribed drugs.

Considering the regulation of the establishment of pharmacies the public interest argument of correction for market failure is even weaker. Why regulate also the entry into the market for community pharmacists if there already is a double registration procedure in order to guarantee good service quality? With respect to the Netherlands, the KNMP advisory establishment policy must be examined more closely to provide an answer to this question. In $\$ 2.3$ the justification used by the KNMP for its establishment policy has been presented: "the financial exploitation of a pharmacy has to be financially sound, and therefore a minimum number of prescriptions is needed." One could ask whether the concept of economic feasibility, which is based on the desired number of prescriptions, has not been defined too narrowly by the KNMP, but to determine this will be very difficult. With respect to Belgium, it is obvious that with the Royal Decrees from 1974 and 1977 and the recently prolonged moratorium, the entry of new pharmacies into the market is regulated in a very restrictive manner. The explanation for this is that the pharmacy density in Belgium has always been very high compared to that of other European countries - and certainly compared to the Netherlands. The operational and transportation costs of the distribution of drugs are high too, because there is a large network of pharmacies and wholesalers and often deliveries are made several times a day to the same pharmacy. Belgium opts for quick and small-scaled deliveries and an individual approach to patients, but it has to pay a price for that in the form of higher costs. ${ }^{41}$ However, the question remains whether it is really in the public interest to have guidelines or rules about the economic feasibility of a pharmacy: Is it after all not up 
to the pharmacist to determine whether he or she thinks it is feasible to enter the market? Again one has the impression that the tool used goes much too far in order to cure the information asymmetry. Because market competition is likely to be severely restricted, in the end the cure may be worse than the disease.

As far as the regulation of fees is concerned, we can be brief. Although there are differences of form between the Netherlands and Belgium, the bottom line is that prices (or fees) are regulated and that price competition is almost totally excluded. Even if there might be a public interest argument to give a monopolistic right to pharmacists to sell some drugs - albeit the question still arises whether the same goal could not be reached via less interventionist means than the ones observed in the Netherlands and Belgium - it should at any rate be possible for them to compete with respect to prices and quality. However, we have shown earlier that there are no possibilities at all for pharmacists to compete by prices. In the Netherlands pharmacists receive a fixed amount per prescription, in Belgium they receive a fixed margin on the sale of drugs. Such tight price regulation is hardly to the benefit of the consumer: There is no possibility to choose between good service/higher price and little service/lower price. This absence of choice constitutes the most important problem from a consumer perspective. According to the present tariff structure, Dutch and Belgian pharmacists are even inclined to sell as many prescribed drugs as possible while giving little or no advice, because they do not get extra money for these time-consuming services. Hence, the current structure of price regulation in the Netherlands and Belgium even has adverse effects on the incentives of pharmacists to increase the quality of their services.

Without price competition as an option, the only way left for pharmacists to compete with others would be in the quality of services. But also that kind of competition is seriously restricted as a result of the regulations we have described, both in the Netherlands and in Belgium. In both countries there is an almost complete prohibition of advertising. This prohibition can hardly be said to serve a public interest goal. It is therefore under serious attack from judges (in Belgium) and competition authorities (in the Netherlands). The same conclusion can obviously be reached as far as the highly restrictive regulations concerning the exercise of the profession in both countries are concerned. Because in the Netherlands pharmacies have to satisfy all the requirements included in the Dutch Pharmacy Standards of 
the KNMP, a differentiation in the provision of services becomes almost impossible. Every pharmacist has to abide by the opening hours, the requirement to have a separate room for magistral preparation of medicines, and the requirement to deliver every sensible prescription. In Belgium, the sixth professional rule defined by the Order of Pharmacists contains requirements that are very similar to those defined in the Netherlands. It goes without saying that for pharmacists the possibilities to compete in quality decrease largely for these reasons. This is not to say that the possibilities of non-price competition are totally excluded. It is theoretically still possible to compete with better services or the offer of a wider range of non-prescription goods. However, it remains difficult to convey these competitive advantages to the consumer, given the prohibition of advertising. Hence, these regulations do not seem to serve a public interest goal either.

In sum, although there seem to be valid reasons for some kind of regulation of the services provided by pharmacists, the profession appears to have "abused" the public interest justification by introducing all kinds of restrictive regulations, which go much further (in limiting competition) than the public interest goal would justify. Hence, the private interest hypothesis might to some extent explain the intensity of the regulations examined.

\section{A Private Interest Analysis of the Regulation of the Dutch and Belgian Pharmaceutical Markets}

The private interest argument: The rent-seeking hypothesis. The private interest (or rent-seeking) hypothesis has originated from the wellknown economic theories that share more or less the same approach towards the formulation of regulation: the capture theory (Bentley, 1908; Hägg, 1997, p. 342; Posner, 1974, pp. 341-342), public choice, and Stigler's economic theory of regulation. The rent-seeking hypothesis originates in particular from a number of works written by economists who are (or were) attached to the Chicago school (Becker, 1983; Buchanan, Tollison, \& Tullock, 1980; Buchanan \& Tullock, 1962; Peltzman, 1976; Posner, 1974).

According to the private interest approach interest groups are continually influencing political decisions in order to seek rents for themselves. Rent seeking will be most successful if groups are small, single-issue oriented, and well organized (Olson, 1965). Professional 
organizations seem to fit most of these criteria: They are small relative to the number of consumers, they are very single-issue oriented, and often well organized. According to private interest arguments, they are therefore better able and more inclined to influence regulatory agencies. Special-interest groups may have such a powerful influence on politicians that their efforts to obtain regulatory failures override general preferences (for empirical evidence of rent seeking by professionals in various European countries, see Faure, Finsinger, Siegers, and Van den Bergh (1993).

Stigler went even further by stating that regulation in general is acquired by the industry and is designed and operated entirely for its benefit (Stigler, 1971, p. 3). ${ }^{42}$ He stated that every branch of industry, which is powerful enough to do this, will lobby the government for the erecting of entry barriers such as obligatory training or apprenticeships, product requirements, taxes, import quotas, etc. The explanation for this lobbying activity is that entry barriers lead to a decrease in the supply of a given product, which in turn leads to an increase in the price, and that is of course favourable to the insiders in the market, viz., the original producers. The same line of reasoning goes for direct rules of conduct like a prohibition to advertise. Advertising bans lead to a less transparent market where the prices asked can and will be higher than in a market without advertising bans.

Becker (1983) points to the fact that regulation can be the result of competition for political influence among many different interest groups. In his analysis Becker even unifies the view that governments correct market failures with the view that they favour the politically powerful: In his model both are produced by the competition for political favours (Becker, 1983, p. 384).

In the remainder of this section, the rent-seeking hypothesis will be tested by analysing the regulatory frameworks of the pharmaceutical market in the Netherlands and in Belgium.

Analysis. We believe that the Dutch and Belgian regulations concerning pharmacies provide a strong case backing up Stigler's hypothesis that regulation is merely used as a barrier to entry with the aim of providing rents to the pharmacies. Some aspects of the regulation in the Netherlands and Belgium we have just discussed seem to aim at a limitation of competition only. This is, e.g., the case with the prohibition of advertising. A prohibition of advertising 
will make the market less transparent. Hence, it will become more difficult for patients to compare service quality between pharmacists. This seems only to serve a private interest goal. The same can be said for the regulation of the exercise of the profession (notably the mandatory design of the pharmacy and related aspects). Of course one could argue that it may be in the public interest that a pharmacy is well-designed, but again the regulations in the Netherlands and Belgium seem to go much further than the public interest goal would require. It is, e.g., not possible for a pharmacy to have opening hours only in the evening, or to provide medicines only for specific groups of patients. A differentiation of pharmaceutical services is hence prohibited by the regulation. This is true both for the Netherlands and Belgium.

It is, however, not always clear who are precisely the "winning" pharmacists in this private interest game. The interests of pharmacists may indeed well be heterogeneous. Some may wish to compete against others in order to gain a larger share of the market, whereas others may wish to be protected from that competition. It is hence not a priori clear that all pharmacists gain from, e.g., a ban on advertising. However, the fact remains that many of these professional rules limit competition and therefore consumer choice. But there again we should repeat that - as far as prescription drugs are concerned - the opportunities for consumer choice among drugs is often non-existent or at least limited to the services that are offered during and after the sale of the drug.

Also the regulation concerning the establishment of a pharmacy seems to constitute evidence of the "barriers to entry" hypothesis. Although there are differences of form between the Netherlands and Belgium, in both countries the self-regulatory bodies can supervise the establishment of pharmacies. The argument that a pharmacy should be "financially sound" (in the Netherlands) and the distance criteria (in Belgium) only serve to limit the number of market participants, but do not provide any guarantee for an increased quality of the services provided. In both cases one can ask whether it is really in the public interest to have guidelines about the economic feasibility of the pharmacy or the distance of a pharmacy to other pharmacies. Again, one has the impression that the tools used in both countries go much further than the public interest goal to be served. By regulating the entry of newcomers to the market, the "insiders" benefit, because there will be less competition in the market. Notice that as 
far as the form of the supervision over the establishment is concerned, there are differences between the Netherlands and Belgium. In the Netherlands the establishment (and limitation) of the pharmacies is based on an "advisory policy," whereas Belgium introduced a formal moratorium on pharmacies in 1994. However, since in the Netherlands the contracts between pharmacists and health insurers are based on the guidelines of the professional body, it will effectively be impossible for pharmacists in the Netherlands to enter the market without consent of the health insurer.

This influence of health insurers (also in the establishment of pharmacies) in the Netherlands points at the fact that this establishment policy might be in the interest not only of the pharmacists, but also of the health insurers. This is linked to another element, which illustrates the private interest character of the regulation, viz., the regulation of fees and tariffs. Although we cannot discuss the role of health insurers within the limits of this paper, it is clear that they have much influence on the drug delivery system. Indeed, in both countries health insurers have an important influence on drug prices and therefore also indirectly on the pharmacist's fee. Health insurers clearly have an interest in keeping prices of pharmaceuticals and fees for pharmacists within reasonable limits. This influence of health insurers therefore provides some support for the hypothesis of Becker that regulation is the result of a competition for political influence among interest groups.

Summary. On the basis of this qualitative analysis of Belgian and Dutch regulation of pharmacists, one can therefore conclude that although there certainly is a public interest argument in favour of regulation, parts of the contents of the regulation are certainly not in the public interest. The tariff regulation, prohibition of advertising and the establishment policy seem to go further than what would be warranted to cure a market failure. This corresponds with the prediction in the literature that a profession will seek to obtain monopoly profits by using regulation to grant them monopoly rights. ${ }^{43}$

However, although the regulation clearly is to some extent promulgated in the interest of the pharmacist, it is also likely that, for example, the fee regulation is the result of competition for regulation among different interest groups. Fee regulation probably promotes the interests of health insurers as well. 
AN EMPIRICAL AND COMPARATIVE ANALYSIS: FIRST RESULTS

It is obviously another question whether the pharmacists in the Netherlands and Belgium are actually successful rent seekers. That is largely an empirical question. As far as the contents of the regulation are concerned, pharmacists in both countries appear to be successful, at least in limiting competition. We will now examine whether the regulation was also effective in limiting the entry into the profession. Therefore we will look at the number of pharmacists (and its evolution) in both countries. In that respect it will obviously be interesting to relate these developments to differences in regulation between both countries. In addition we will examine whether these barriers to entry also lead to rents for pharmacists in both countries. We will try to provide some evidence on the relative income of pharmacists and some indication of takeover prices.

\section{The Number of Pharmacies}

The evolution over time of the number of pharmacies (community pharmacies, dispensing physicians and hospital pharmacies together) in the Netherlands is shown in Figure $1 .^{44}$ The effects of the KNMP establishment policy are visible in this figure. During the period in which the policy was obligatory for KNMP members (1975-1987) we see a decrease in the number of pharmacies. After 1987 the number eventually increased again, but it is obvious that also the advisory establishment policy - enacted in 1987 - was able to prevent the number of pharmacies to reach the 1970 level of 2,298. The initial increase was therefore temporary. In 1998 the number of pharmacies was only 2,244 (divided into 1,547 community pharmacies, 605 dispensing physicians and 92 hospital pharmacies).

If we then look at Figure 2, which indicates the relationship between the number of community pharmacies and dispensing physicians, it appears that for almost every new community pharmacy a dispensing physician gave up his or her drug depot. ${ }^{45}$ In 1982 the number of established pharmacists on the market was for the first time larger than the number of dispensing physicians. It seems that newcomers to the pharmaceutical market are more or less dependent on the possibilities of "buying out" a dispensing physician or a pharmacist who is willing to give up his or her practice.

In a market without population growth this might be nothing to 


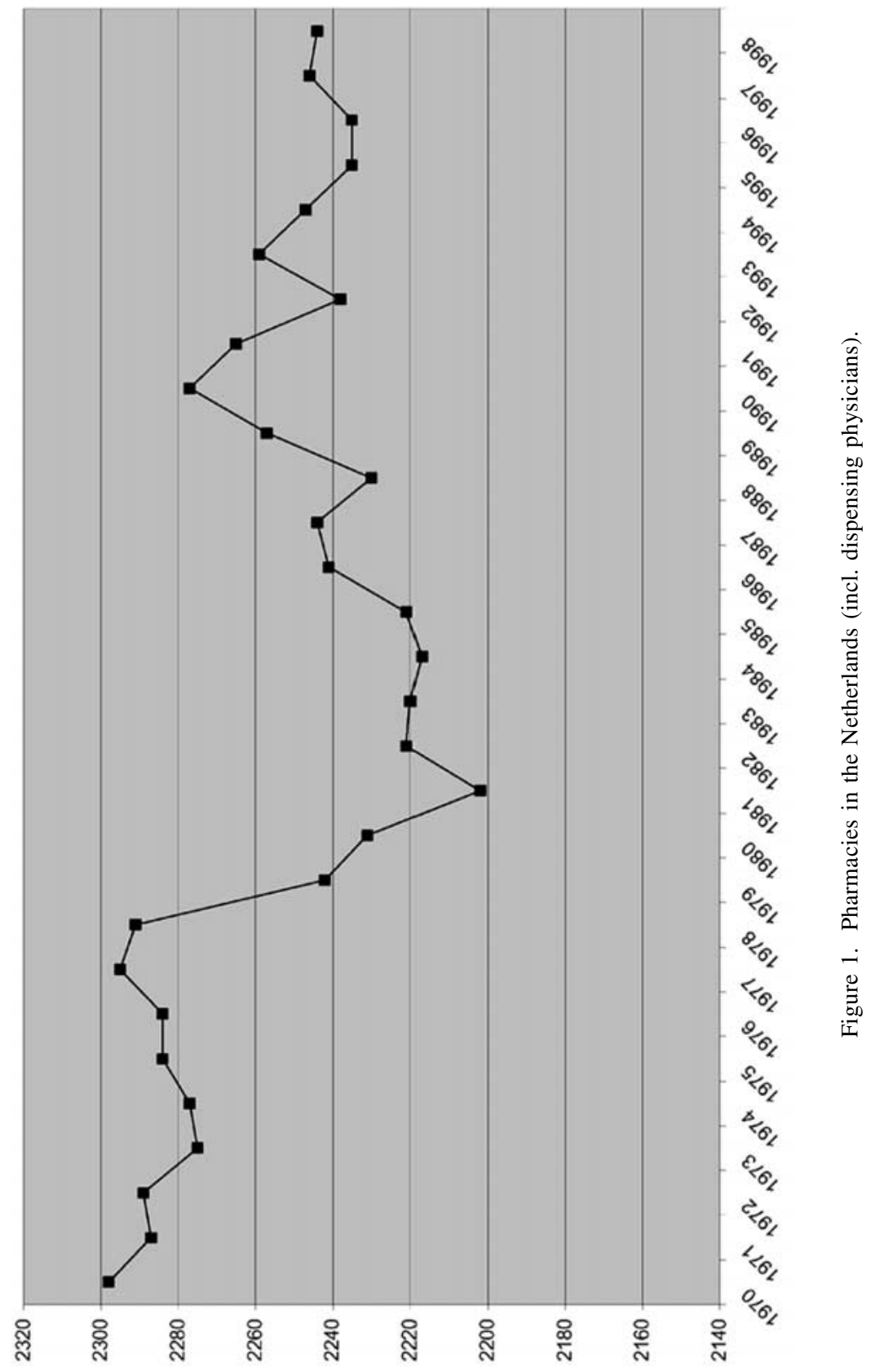




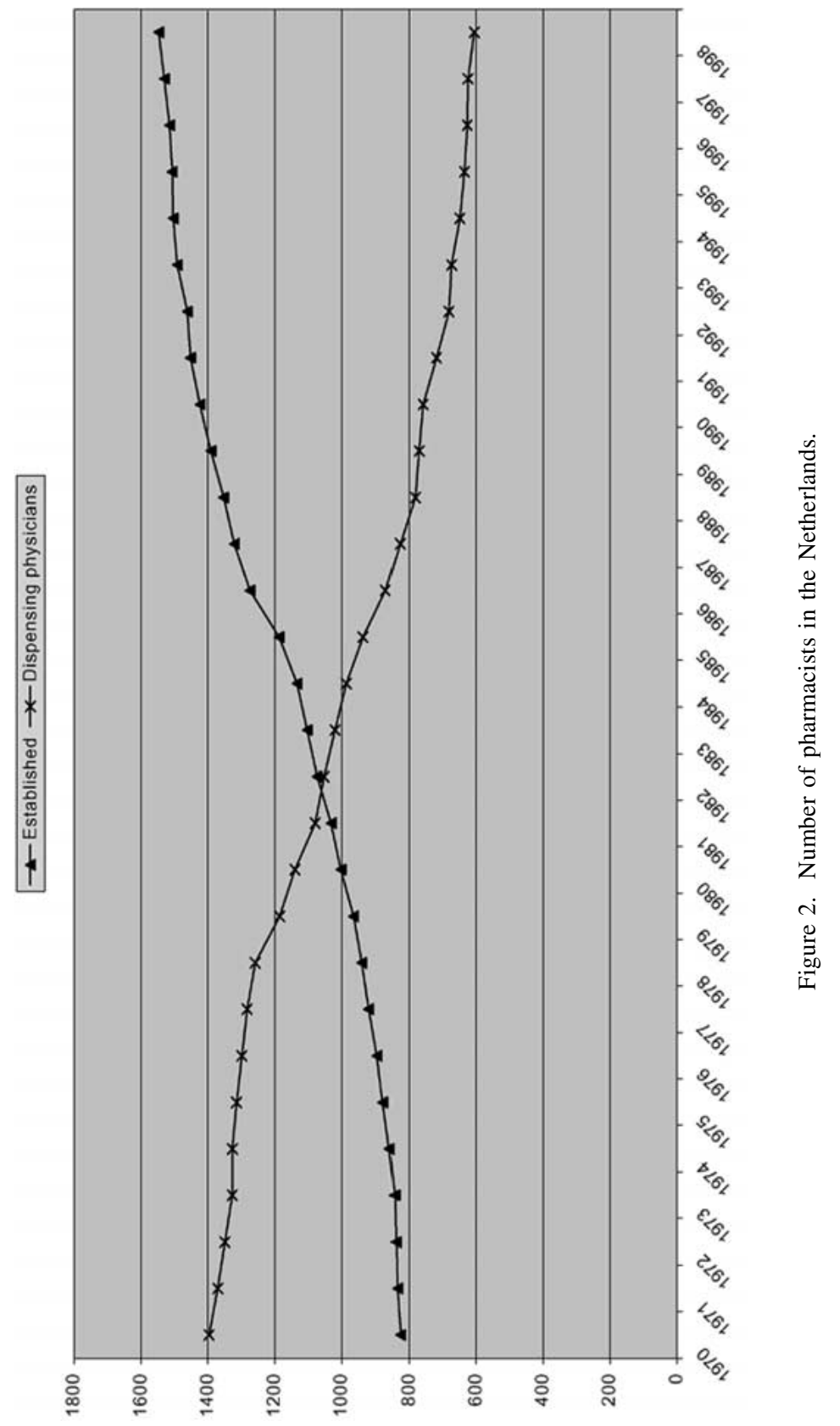


really worry about (that is, if the initial number of pharmacies would have been optimal at the outset), but in the Netherlands, like in all of Europe, the population has increased enormously during the last decades. The number of patients per pharmacy increased from 5,834 in the year 1970 until 7,274 in the year 1998, as shown in Figure 3.

While, of course, this presentation of the number of pharmacies in the Netherlands cannot be explained by the KNMP establishment policy alone (also the drug policy or the evolution of the profession itself may be responsible), it does provide some tentative evidence of rent seeking. Thus these data on the evolution of the number of pharmacies provide some support for the qualitative analysis presented above. A comparison with other countries seems necessary to draw further conclusions, although such an analysis will certainly not be easy because of the many differences in the regulation of the pharmaceutical profession across Europe. However, within the scope of this paper we can of course provide a comparison with the Belgian situation.

With the exception of Greece, Belgium has the tightest web of pharmacies in Europe. ${ }^{46}$ On average there was one pharmacy for 1,935 inhabitants in 1998. Figure 4 shows that the number of patients per pharmacy in Belgium decreased between 1961 and 1986, but since then, while the Belgian population kept increasing, this number has increased very slowly. ${ }^{47}$

Figure 5 presents the number of community (established) pharmacies in Belgium. As opposed to the Netherlands, we see an increase in this number, although since the mid-1980s the number of community pharmacies has remained almost constant. It seems therefore that the public regulations in Belgium did a reasonable job in reducing the number of new pharmacies. The reason for this regulation of establishment of pharmacies is different from the one the KNMP uses in the Netherlands, because in Belgium the government fears an "oversupply" of pharmacies. Because the number of pharmacists active on the Belgian market is still very high (much larger than the Dutch number), it will remain difficult for Belgian pharmacists to open a new pharmacy.

Although we noticed that today both Belgium and the Netherlands have strict rules concerning the establishment of pharmacies, there still are considerable differences between the two markets. Whereas in the Netherlands in 1998 there were 7,274 patients per pharmacy, the average number of patients for one pharmacy in Belgium was 1,935. 


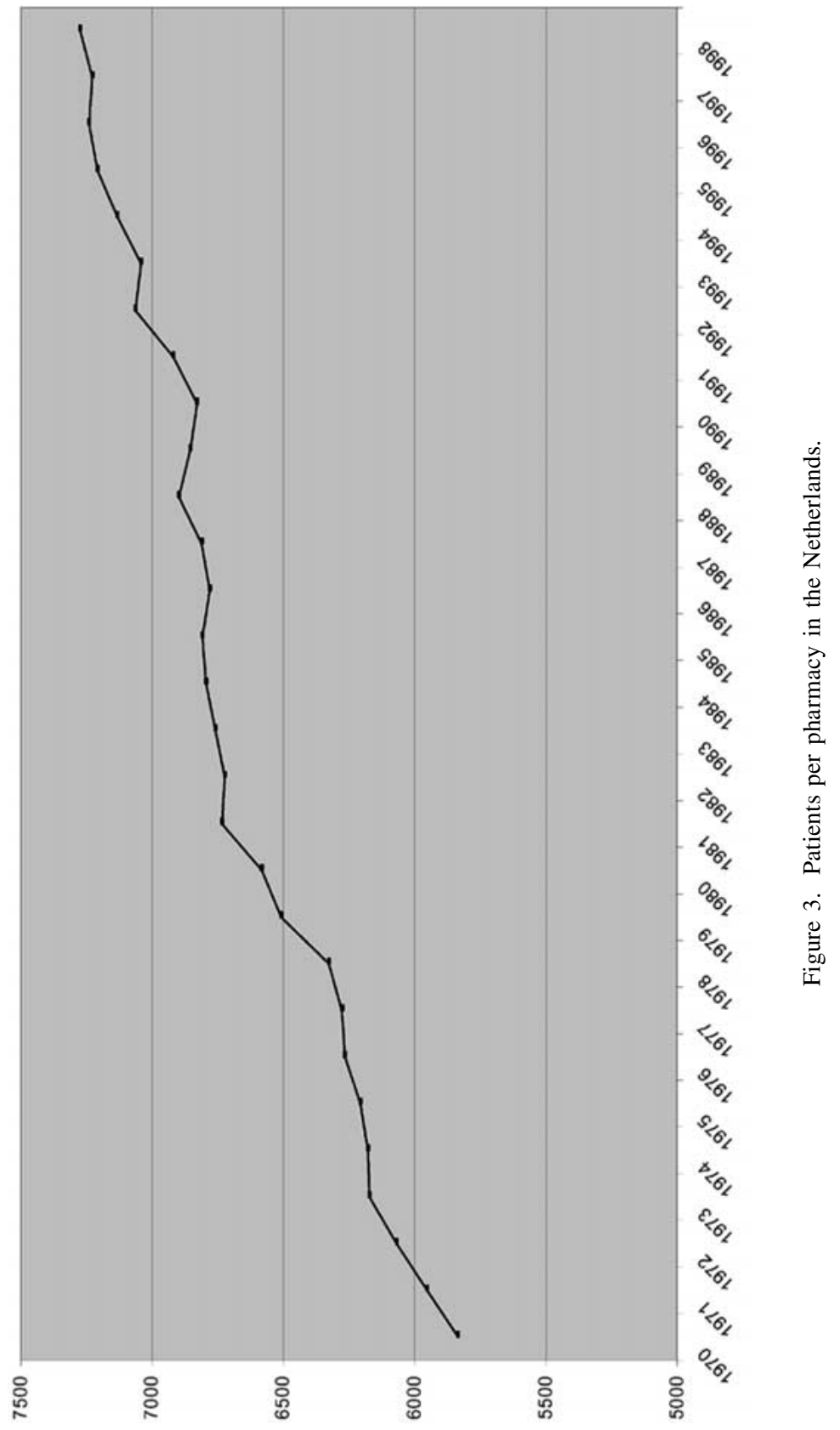




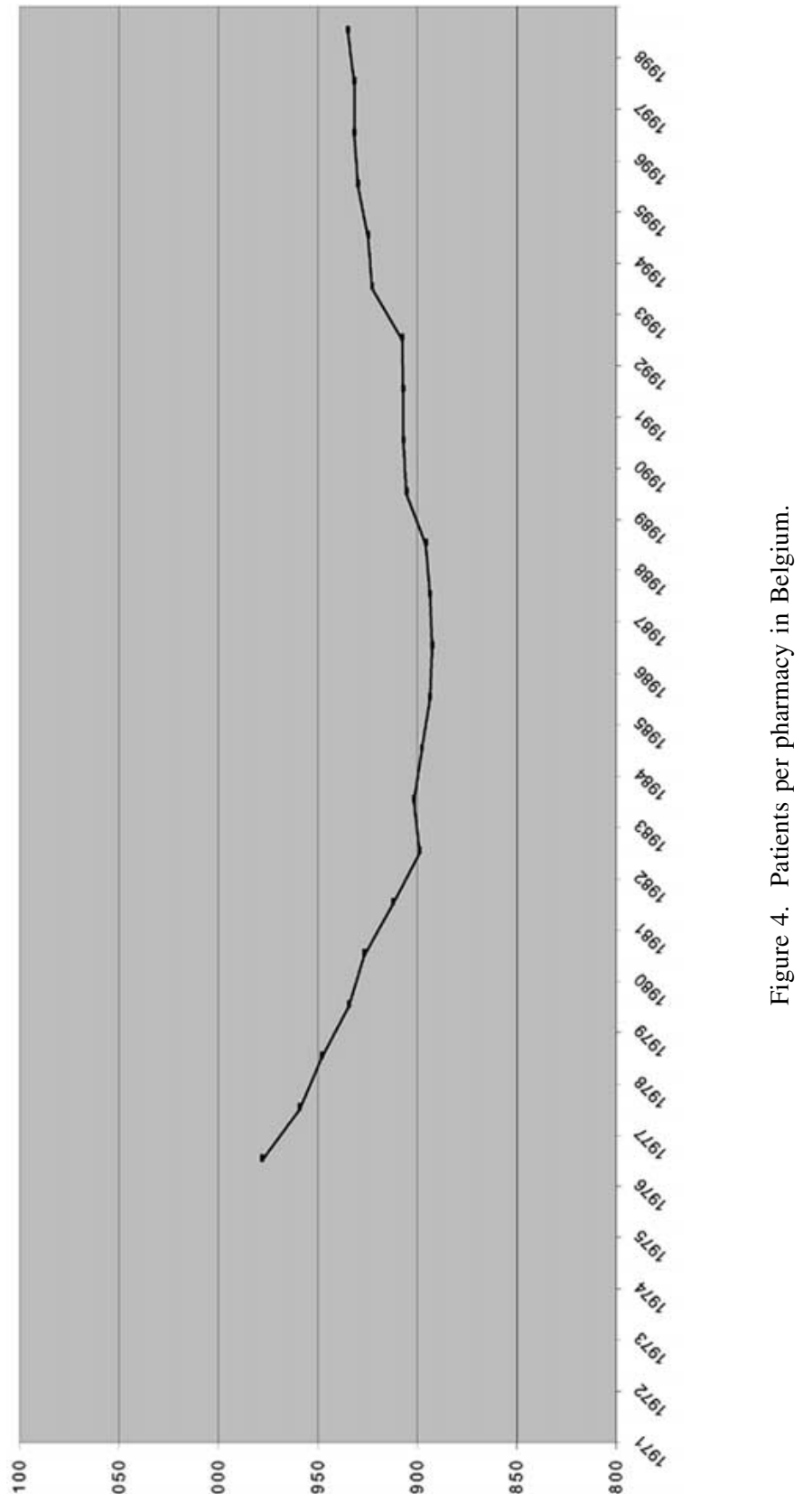




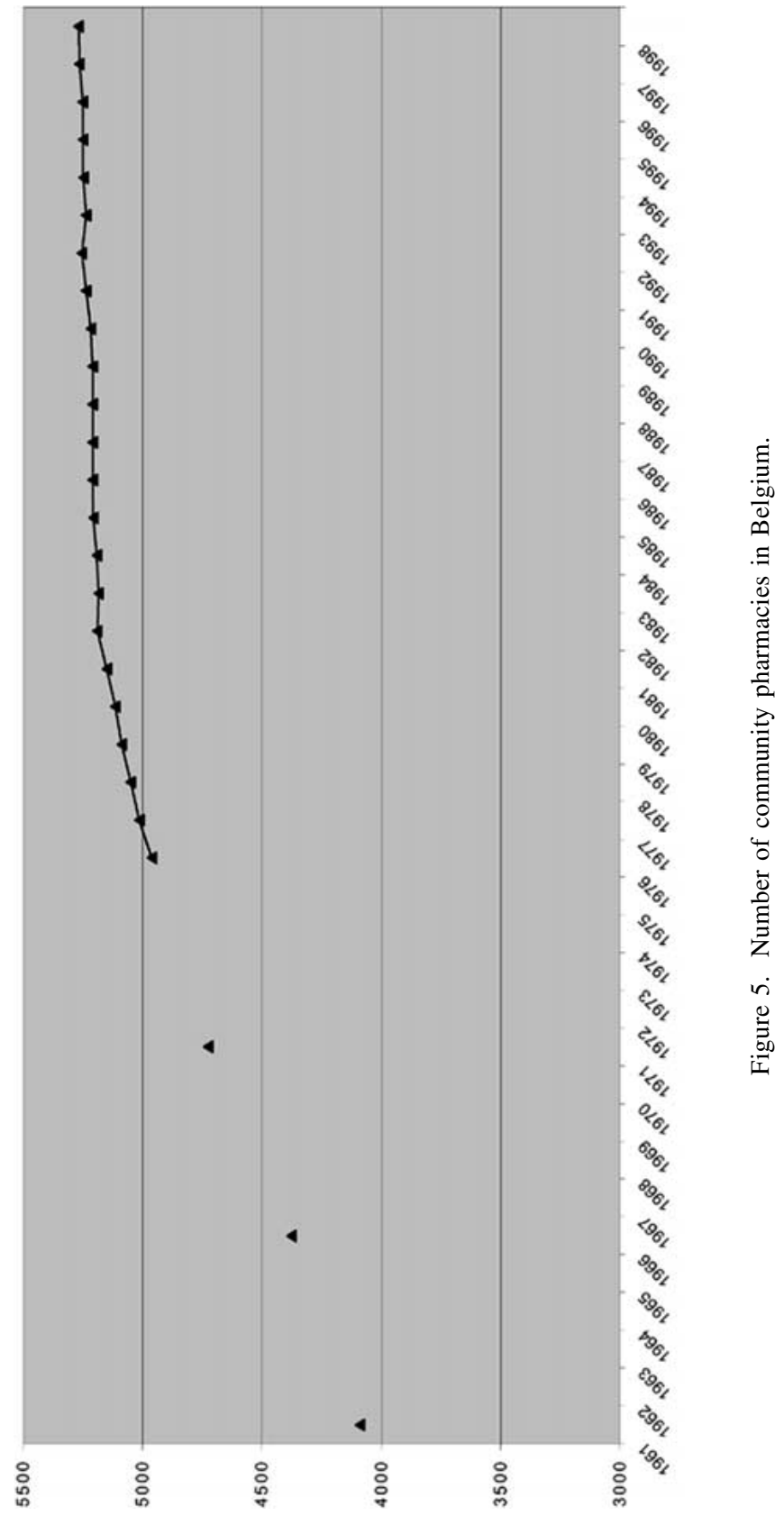


Hence, one could conclude that the Dutch pharmacists have apparently been far more successful in limiting market entry than their Belgian colleagues. That large difference cannot be explained by merely looking at the contents of the rules of establishment, which are today very strict in both countries. One has the impression that the Dutch started much earlier to limit market entry than the Belgians. By the end of the seventies, the Dutch (private) regulations apparently succeeded in reducing an already small number of pharmacies even further. The Belgian moratorium on the establishment of pharmacies came only in 1994, when the number of pharmacies was already large. It succeeded in limiting the growth of the number of pharmacies, but the average number of pharmacies remains high.

\section{The Income of Pharmacists}

Another way of getting an indication of the success of rent seeking by pharmacists is by examining data on their incomes. The average income of a profession might give some estimate of its success in obtaining rents. However, one should be very careful with the interpretation of such data; high incomes do not necessarily emanate from high rents as a result of rent seeking (e.g., lobbying or self-regulation). Nevertheless, income data are still interesting if one wants to compare one profession with others.

Since we just noticed that the average number of patients per pharmacy is a lot higher in the Netherlands than it is in Belgium, one would expect that on average the incomes of Dutch pharmacists would be higher than those of their Belgian colleagues. That is, unfortunately, impossible to ascertain. Data on the incomes of Dutch pharmacists are extremely difficult to find, not least because a large part of their income depends on the bonuses and discounts received from the pharmaceutical industry. We do know, however, that the average turnover of a Dutch pharmacy in 1999 was $€ 1,810,583$ (SFK, 2000 , p. 54). The gross profit at this turnover would be $€ 376,638$ (according to the SFK), which implies a gross profit margin per pharmacy of almost $21 \%$. However, this amount is exclusive of bonuses and discounts. If we add the bonuses and discounts and then compute the gross profit margin for a Dutch pharmacy, it would be almost $26 \%$. The average bonuses and discounts per pharmacy are about $€ 90,756$ (according to our own calculations based on numbers given by the SFK and PriceWaterhouseCoopers). ${ }^{48}$ 
It is difficult to compare these data with Belgian data, since the Dutch data represent the turnover, which is obviously not the same as income. However, some comparison between Dutch gross profit and Belgian incomes may be possible. We will come back to that below. First it seems interesting to look at the Belgian data alone, since they allow for some comparison with other professions. In Figure 6 the income of Belgian pharmacists is compared to the income of three other professions and the income of the average self-employed. ${ }^{49}$ The numbers show that in Belgium the income of all professions exceeds the income of the self-employed workers, although the architects' income is very close to that of the self-employed. The data also suggest that the relative income of pharmacists is quite high: Until the early 1990s, the average income of pharmacists was even higher than the average income of physicians. The pharmacists' income is significantly higher than the attorney's income as well. Hence, there is at least some tentative evidence that Belgian pharmacists as a group might be efficient rent seekers. However, we have to keep in mind that high incomes do not necessarily result from rent-seeking behaviour, but may also be, for example, a reward for investments in prolonged education. However, the average income seems to be substantially higher than what could be expected as postponed income caused by longer studies. Hence, a part of this reward can be considered as rent. A similar conclusion concerning the relative success of professionals in rent-seeking was reached in an earlier Belgian paper by Faure and Van den Bergh (1991), based on an examination of data from attorneys, architects, physicians, and pharmacists between 1982 and 1988.

Unfortunately we cannot compare these nice Belgian data with Dutch data, since the latter are not available. We do however know that the gross profit (before taxes, before deduction of costs) of an average pharmacy in the Netherlands in 1999 was $€ 376,637 .{ }^{50}$ This can to some extent be compared to the Belgian data, which provide income before taxes, but after deduction of costs. If we take the data provided by SFK on the average costs of pharmacists in the Netherlands ${ }^{51}$ and subtract these from the gross profit mentioned above, the average income of a Dutch pharmacist would be $€ 69,641$. In 1999 in Belgium the average income of a pharmacist was $€ 47,360 .^{52}$ That the Belgian figure is substantially lower than the Dutch should not come as a surprise, given the fact that the average Dutch pharmacy has more than three times as many patients as the 


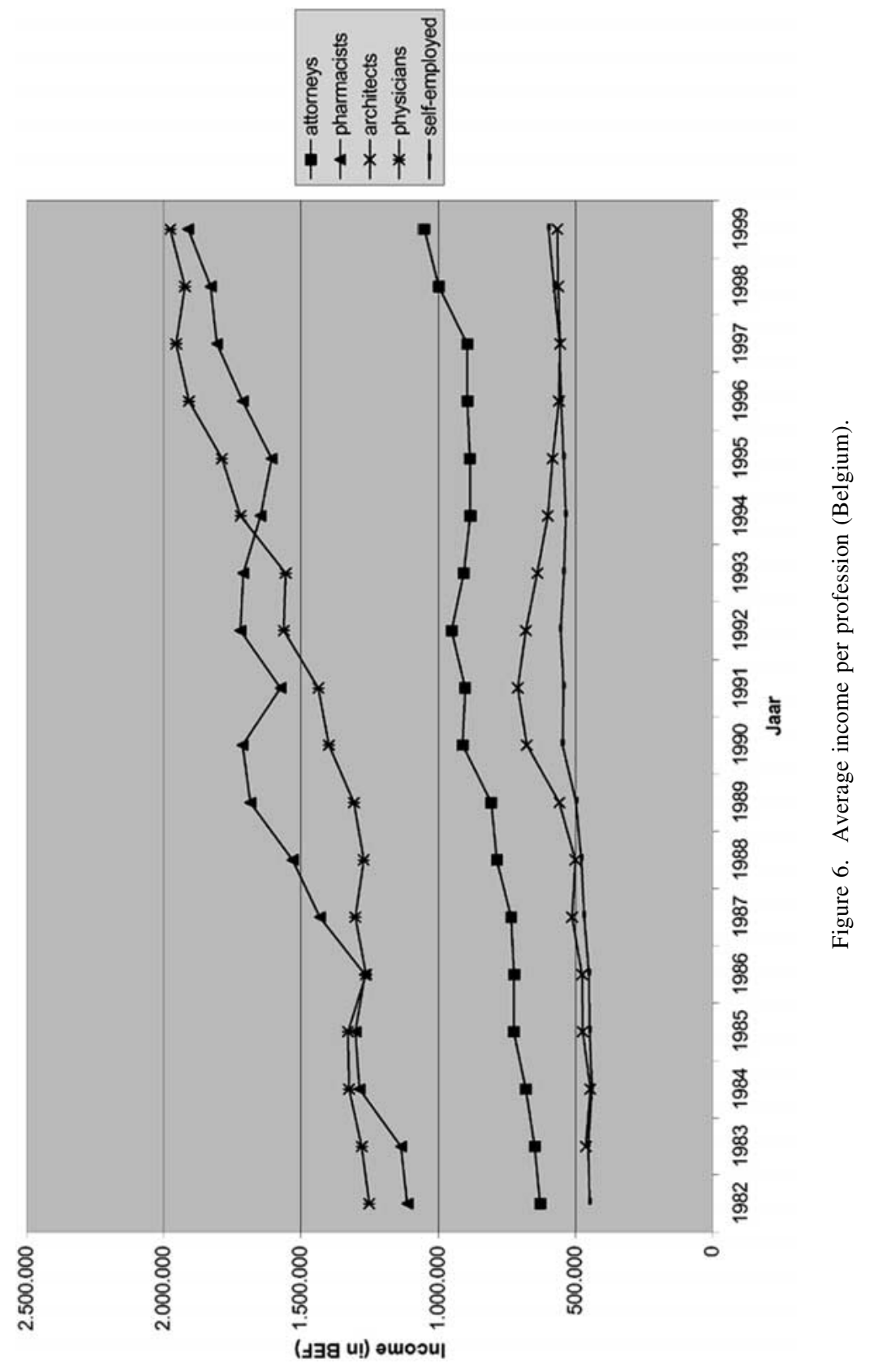


Belgian counterpart. Moreover, if we would also include the estimated amounts of bonuses and discounts received by pharmacists in these computations, the difference would be much larger yet.

In sum: Even though Belgian pharmacists seem to be successful rent-seekers at the national level, if one compares their income to, e.g., that of a Belgian architect, they do relatively poorly compared to their Dutch colleagues. Obviously that must to a large extent be due to the average number of patients per pharmacy. However, one should be careful in attributing this difference solely to a difference in the relative lobbying force of the pharmacists in the two countries. It may well be imbedded in cultural differences as well. The fact that the Belgian public apparently expects quick service offered by a large body of pharmacists will also have some influence on the "optimal" number of pharmacists in a society.

\section{Takeover Regulation}

Takeover prices can be considered as a powerful indicator of rentseeking as well. The mere fact that goodwill is paid for the takeover of a pharmacy proves that the pharmacy itself has a value, other than the value of the real estate, the stocks, etc. Hence, this confirms Moore's hypothesis that a license will confer property rights upon the licensees (Moore, 1961). The practice in both countries shows that the "license" to operate a pharmacy has a real and high value. Indeed, it is obvious that the large amounts of goodwill that have to be paid both in the Netherlands and in Belgium restrict the entry into the market as well. Even if a pharmacist would be able to establish a new pharmacy despite the strict establishment rules discussed above he or she would face the problem of having to pay extraordinary large amounts of money for goodwill.

Dutch pharmacists who want to set up their own practice by taking over an existing pharmacy have to pay takeover costs consisting of housing, stock, and an amount for goodwill. The amount for goodwill is often very high and is as a minimum equal to the annual turnover, but often even higher. Considering that as mentioned above the average pharmacy has an annual turnover of about $€ 1,810,583$, it immediately becomes clear that the average goodwill contributes a substantial amount. Moreover, in recent years one has seen a considerable increase in this amount (Jong, 1998, pp. 612-613, and an interview with an anonymous Dutch pharmacist, 24 July, 1999). Thus it is clear that 
especially for recently graduated Dutch pharmacists it will be nearly impossible to set up their own practice right after graduation. Also in Belgium very large sums have sometimes to be paid when taking over a pharmacy, this despite the regulated takeover prices. ${ }^{53}$ Due to the high prices that have to be paid many pharmacies taken over in Belgium are now bought by commercial chains or private individuals who are not pharmacists. About $20 \%$ of the pharmacies in Belgium belong to non-pharmacists. However, it also occurs that established pharmacists buy up pharmacies to form minichains. ${ }^{54}$

Although we do not have data on the exact amounts of goodwill to be paid by aspiring pharmacists, already the fact in itself that in both countries a certain large sum of money has to be paid for goodwill suggests that there are rents that can be captured by the already established pharmacists.

\section{CONCLUSION}

The starting point of this paper was the question of the extent to which the regulation of the pharmaceutical market in the Netherlands and in Belgium can be explained as a result of rent-seeking behaviour by pharmacists or other interest groups. Indeed, we found some evidence for Stigler's private interest hypothesis of rent-seeking behaviour by pharmacists. In addition, some regulations seemed to be a result of competition among interest groups for political influence, as predicted by Becker.

If one looks at the regulatory framework in the Netherlands and in Belgium, a number of restrictions on competition can be found. In both countries there is a double registration procedure with title protection, be it in slightly different forms. Dutch and Belgian pharmacists have a monopoly of compounding and dispensing of (prescribed) medicines. Although adverse selection in the quality of pharmaceutical services seems to justify regulation because of the informational asymmetry between the pharmacist and the patient, these Dutch and Belgian regulations go much too far if the goal were only to promote public interest. The entry into the market (the establishment of new pharmacies) is also regulated in the Netherlands and Belgium. In the Netherlands there are guidelines issued by the pharmacists' association KNMP, which in practice are followed by all health insurers when they make contracts with individual pharmacists. 
In Belgium the government regulates the entry of newcomers into the market, as well as the takeover prices of pharmacies. There seems to be no valid public interest justification for this severe restriction of market competition in the form of entry regulation. One has the impression that the tool applied goes much further than to cure the information asymmetry in both countries. Next to that, in both countries the self-regulatory body of pharmacists prohibits advertising by individual pharmacists. Moreover, the Dutch KNMP and the Belgian Order of Pharmacists have limited the differentiation of services by individual pharmacists, by having formulated all kinds of provisions in the rules of conduct and the deontological rules, respectively. It is obvious that these rules are at least to some extent promulgated in the interest of the pharmacist. Finally, in both countries the fees received by pharmacists are completely regulated. In the Netherlands pharmacists receive a fixed fee for every dispensed prescription, while in Belgium they receive a fixed margin for every dispensed drug. Although this regulation does not seem to serve any clear private interest goals, it is certainly not in the public interest either. Moreover, this fee regulation may promote the interests of health insurers.

We can conclude that the Dutch and Belgian pharmaceutical markets are overregulated and not transparent. A qualitative public and private interest analysis of the regulations in these markets has shown that some of these regulations can only be explained by private interest arguments. We also tried to analyse whether differences in regulation between the Netherlands and Belgium might to some extent explain the effectiveness (success) of pharmacists' rent seeking. We considered the evolution of the number of pharmacists, the (relative) average income of pharmacists, and the issue of goodwill.

With respect to the number of pharmacies, there are considerable differences between the Netherlands and Belgium. In Belgium the number of pharmacies is much higher than in the Netherlands, but the effect of the establishment policy is visible in both countries. The reasons behind the establishment policy differ between the countries, however. In the Netherlands the reason is a restriction of entry by the incumbent pharmacists to guarantee "financially sound" pharmacies, while in Belgium the government tries to regulate the "oversupply" of pharmacies. It follows that the number of patients per pharmacy in Belgium is also much higher than the Dutch one. Moreover, in Belgium this number has been more or less constant (slightly decreasing at first and now slightly increasing) during the last 
decades, while in the Netherlands the number of patients per pharmacy is low and has always been increasing. One has the impression that the Dutch started much earlier with limiting market entry than the Belgians and that they succeeded in reducing an already small number of pharmacies even further.

The data on the average incomes of pharmacists suggest that Dutch pharmacists have higher incomes than their Belgian counterparts (although Belgian pharmacists do relatively well relative to a number of other professionals in Belgium). Obviously this difference will to a large extent be due to the average number of patients per pharmacy. However, one has to be careful with interpreting income data, since high incomes do not necessarily emanate from higher rents as a result of rent-seeking behaviour. Also, it is difficult to obtain data on the average pharmacist's income (especially concerning the Netherlands) and the data we found could not be compared with one another without making some additional assumptions.

We also considered the "goodwill-problem". Both in the Netherlands and in Belgium pharmacists who want to take over a pharmacy have to pay large amounts of money for goodwill. This practice shows that the license to operate a pharmacy has a real and high value (over and above the value of real estate, stocks, and such). The fact that high amounts of money have to be paid for goodwill already suggests that there are rents that can be captured by pharmacists.

Although we found qualitative and quantitative proof for the arguments put forward by the private interest approach of regulation, the question of whether Dutch or Belgian pharmacists are successful rent-seekers remains a difficult one to answer, because plentiful (difficult-to-obtain) data are needed to make strong claims. Hence, this question remains an open one that is certainly worth further research, not only within the framework of the countries dealt with in this paper but also with respect to other countries.

\section{NOTES}

Wet van 18 januari 1996 betreffende de kwaliteit van zorginstellingen (Kwaliteitswet Zorginstellingen), Stb. 80, 1996.

2 See $S t b .20,1999$.

$3 t b .655,1993$, amended by Stb. 570, 1997.

4 Illegal use of a title protected by this Act can be punished with a fine of not more than NLG 5000 (€ 2269). See Article 100. 
5 This norm was not based on financial calculations. It was based on the then existing subscription system (abonnementssysteem) with respect to pharmaceutical care for patients of national health services. According to that system, which remained in force until January 1988, pharmacists received a fixed amount per registered patient irrespective of the actual drug use. The earnings from this subscription system accounted for a substantial part of a pharmacist's gross profit. Since January 1, 1988, pharmacists have received a fee per prescription: the fixed fee (receptregelvergoeding). See KNMP (1997, p. 6).

6 See, e.g., Rb. Maastricht, 15 July, 1981, Tijdschrift voor Gezondheidsrecht, 1982, p. 88 and Rb. 's-Gravenhage, 12 June, 1985, Tijdschrift voor Gezondheidsrecht, 1986, p. 232.

7 These are numbers for the year 1997. The starting point of the calculations is a disposable income of 40,000 NLG (about $€ 18,151$ ), excluding net living expenses of 12,000 NLG (about $€ 5,445$ ). For the complete calculation, see KNMP (1997).

8 Gerechtshof 's-Hertogenbosch, 14 May, 1996, Tijdschrift voor Gezondheidsrecht, 1997, p. 66.

9 Commissie Economische Mededinging, Advies over Ontheffingsverzoek KNMP: Besluit Marktverdelingsregelingen, brief aan de Minister van Economische Zaken, 23 October, 1997.

$10 \quad$ Stb. 545, 1995.

11 Health Charges Board (College Tarieven Gezondheidszorg). Among the tasks of this government watchdog body are the supervision and registration of all drugs (proprietary, parallel-imported, and generic) that have been put into circulation.

12 The Drug Prices Act defines maximum prices for drugs. The Drug Reimbursement System determines the maximum amount of reimbursement by health insurance funds for (clusters of therapeutically mutually interchangeable) drugs. Both are updated regularly.

13 With this a saving of $€ 17.7$ million was intended. The underlying idea was that it is an elementary duty of a pharmacist to dispense efficiently and that therefore the incomes from the incentive measure should be included in the calculations of the fixed fee (MinVWS, 1999a).

14 Split up per product category, 85\% of the turnover of an average pharmacy in 1998 was determined by WTG drugs, against $7 \%$ by non-WTG drugs, $4 \%$ by medical devices, and $4 \%$ by OTC. See SFK (1999, p. 52).

15 B.S. 14-11-1967. Since this is a numbered Royal Decree, it can also change a law. A numbered Royal Decree works like a formal act.

16 Koninklijk Besluit van 29 mei 1970 tot regeling van de organisatie en de werking der raden van de Orde der apothekers, B.S. 4-7-1970.

17 Arbitragehof nr. 68/93, 29 September, 1993, B.S. 28-10-1993, 23.557.

18 Article 16 of the Royal Decree no 80 concerning the Order of Pharmacists.

19 Koninklijk Besluit nr. 78 van 10 november 1967 betreffende de uitoefening van de geneeskunst, de verpleegkunde, de paramedische beroepen en de geneeskundige commissies, B.S. 14-11-1967.

20 The penalty for the practice of a reserved operation is an eight day's to six month's imprisonment and/or a fine of between $500 \mathrm{BEF}$ and $5000 \mathrm{BEF}$ (between $€ 12.39$ and $€ 123.95$ ). See Royal Decree no 78, Article $38 \S 1$. These fines will be raised by a multiplier (the so-called opdeciemen) to correct for currency depreciation. Currently the multiplier is 200 .

21 Drug Act from 1964 (Wet van 25 maart 1964 op de geneesmiddelen), B.S. 17-41964, Articles 1-3 and $6 \$ 1$.

22 A Medical Commission consists of a chairman and a vice-chairman, who are proposed by the national board of the Order of Physicians and appointed by the King; 
and in addition two members for every medical profession, plus one member for every paramedical profession (if recognized by the King).

23. Wet van 12 april 1958 betreffende de medisch-pharmaceutische cumulatie, B.S. 20-6-1958, Articles 1-4 and 9bis.

24 Koninklijk Besluit van 25 september 1974 betreffende de opening, de overbrenging en de fusie van voor het publiek opengestelde apotheken, B.S. 5-10-1974.

${ }_{25}$ Koninklijk besluit van 13 april 1977 tot vaststelling van de regels die toelaten de waarde van de overdracht der apotheken vast te stellen en toezicht uit te oefenen op deze overdracht, B.S. 28-5-1977.

26 B.S 18-10-1994.

27 Koninklijk Besluit van 8 december 1999 tot wijziging van het KB van 25 september 1974, B.S. 14-12-1999.

${ }_{28}$ Hof van Cassatie, 7 Mei, 1999, R.W., 1999-2000, p. 112.

29 Formally the Court of Appeal of the Order of Pharmacists can take a new decision after a cassation decision. If then a second decision of the Court of Cassation follows, that one is final.

30 Het Belang van Limburg, Vrije beroepen moeten vrij kunnen concurreren, 24 August, 1999.

31 De Juristenkrant, Na de advocaten, nu de apothekers, September, 1999.

32 NMa, Decision nr. 397/1998. See also later cases on, e.g., notaries (nr. 952/1999) and general practitioners (nr. 537/2001).

33 Koninklijk Besluit van 3 juli 1969 betreffende de registratie van geneesmiddelen, B.S. 10-7-1967.

${ }^{34}$ Koninklijk Besluit van 2 september 1980 tot vaststelling van de voorwaarden waaronder de verplichte ziekte- en invaliditeitsverzekering tegemoetkomt in de kosten van de farmaceutische specialiteiten en daarmee gelijkgestelde produkten.

35 See Article 5 of the Royal Decree of 2 September, 1980.

36 In mid-2001 the Belgian government started an information campaign to promote generic drugs and lowered the reimbursement of some expensive branded drugs that have (equal) generic substitutes. However, at the time of writing of this article the effects of those measures are still unclear. See, e.g., De Standaard, Overheid voert campagne promotie generische medicijnen (28 May, 2001) and De Standaard, Positieve reacties op prijsverlaging (20 April, 2001).

37 De Standaard, Apothekers vragen opslag, 24 October, 1998.

38 For Belgium the margin on drugs can be subdivided as follows for the year 1997: $64.7 \%$ for the producers, $8.3 \%$ for the wholesalers, and $27 \%$ for the pharmacists. See PriceWaterhouseCoopers (1999, p. 21).

39 For a discussion of Pareto optimality and market failure, see, e.g, Mamuth (1992, pp. 119-128; 181-190); Tirole (1992, pp. 6-7; 106-114); Varian (1984, pp. 190-209; 253-262).

40 This is true if one considers the services of a pharmacist like giving drug advice and medication guidance a specific service. The mere selling of prepacked drugs cannot be considered a "service" in the strict sense of the word.

${ }_{41}$ Antwerps Farmaceutisch Tijdschrift, 12, 1998, pp. 26-27.

42 Stigler's theory has been formalized and extended by Peltzman (1976).

43 Shaked and Sutton (1981) provide a model that offers strong support for the argument that the granting of monopolistic powers to a self-regulating profession is likely to be welfare-reducing. Gehrig and Jost (1995) conclude in their paper that even with asymmetric information in a market, self-regulation is socially desirable only if the regulator values firms' profits sufficiently highly (the analysis can also be applied to professionals). 
44 Data sources for Figures 1-3: Dutch Bureau of Statistics (CBS), Eurostat and own calculations.

45 Articles 6 and 7 of the Drug Supply Act of 1958 state that dispensing physicians may only be established in areas where no pharmacist is established.

46 Het Nieuwsblad, Apothekers willen minder apotheken, 4 November, 1998.

47 Data sources for Figures 4-5: BIGE (1999), Eurostat, and own calculations.

48 We divide the total number of bonuses and discounts by the number of established pharmacies and dispensing physicians.

49 Data source: National Institute for Statistics (NIS).

50 Here we do not take into account the crude data on bonuses and discounts.

51 To estimate these costs, we added the figures for practice costs, housing costs, general costs, computer costs, interest, writing-offs, and car costs presented in SFK (2000, p. 50) to arrive at an average amount of $€ 306,996$.

52 We have to be very careful in interpreting these numbers, because they come from different sources and, moreover, are rather crude (especially the Dutch data). However, because the difference suggested here between the average income of Dutch and Belgian pharmacists is so huge, we can still draw some tentative conclusions.

53 Het Nieuwsblad, Apothekers willen minder apotheken, 4 November, 1998.

${ }^{54}$ Antwerps Farmaceutisch Tijdschrift, 4, 1999, p. 17.

\section{REFERENCES}

Akerlof, G. (1970). The market for lemons: Quality, uncertainty and the market mechanism. Quarterly Journal of Economics, 85, 488-500.

Balthazar, T. (1994). Substitutie van geneesmiddelen. Vlaams Tijdschrift voor Gezondheidsrecht, 2, 107-136.

Becker, G. S. (1983). A theory of competition among pressure groups for political influence. Quarterly Journal of Economics, 98, 371-400.

Bentley, A. F. (1908). The process of government. Chicago: University of Chicago Press.

BIGE (1999). Compendium Gezondheidsstatistiek 1999. Brussel: Belgisch Instituut voor Gezondheidseconomie.

Buchanan, J. M., Tollison, R. D., \& Tullock, G. (Eds.) (1980). Toward a theory of the rent-seeking society. College Station, TX: Texas A\&M University Press.

Buchanan, J. M., \& Tullock, G. (1962). The calculus of consent. Ann Arbor, MI: University of Michigan Press.

Demeester, H. (1990). Twintig jaar vestigingswet voor apotheken. Hospitalia, $117-119$.

Faure, M., Finsinger, J., Siegers, J., \& Van den Bergh, R. (Eds.) (1993). Regulation of professions: A law and economics approach to the regulation of attorneys and physicians in the U.S., Belgium, the Netherlands, Germany and the U.K. Antwerpen: MAKLU.

Faure, M., \& Van den Bergh, R. (1991). Self-regulation of the professions in Belgium. International Review of Law and Economics, 11, 165-182.

Gehrig, T., \& Jost, P. (1995). Quaks, lemons and self-regulation: A welfare analysis. Journal of Regulatory Economics, 7, 309-325.

Hägg, P. G. T. (1997). Theories on the economics of regulation: A survey of the literature from a European perspective. European Journal of Law and Economics, 4, 337-370. 
Jong, J. G. A. M. de (1998). Apothekers zijn ondernemende zorgverleners. De Accountant, 104, 612-614.

KNMP (1993). Beroepscode en gedragsregels van de KNMP. The Hague: Koninklijke Nederlandse Maatschappij ter bevordering der Pharmacie.

KNMP (1996). Nederlandse Apotheeknorm: Norm voor de farmaceutische zorgverlening door de openbare apotheek. The Hague: Koninklijke Nederlandse Maatschappij ter bevordering der Pharmacie.

KNMP (1997). Minimum vestigingsnorm voor apotheken. The Hague: Koninklijke Nederlandse Maatschappij ter bevordering der Pharmacie.

KNMP (1998). Pharmacy in the Netherlands: Special issue 1988. The Hague: Koninklijke Nederlandse Maatschappij ter bevordering der Pharmacie.

Leenen, H. J. J. (1991). Handboek gezondheidsrecht: Gezondheidszorg en recht. 2nd ed. Amsterdam: Samson.

Mamuth, H. A. (1992). Markteconomie: Analyse en evaluatie. 3rd ed. Utrecht: Maastricht University.

MDW (1999). Rapport 1 december 1999, Project Marktwerking Deregulering en Wetgevingskwaliteit. The Hague: MDW-werkgroep Geneesmiddelen.

MinVWS (1999a). Aanwijzing stimulansopbrengst in de tarieven farmaceutische zorg (29 June, 1999). The Hague: Ministerie van Volksgezondheid Welzijn en Sport.

MinVWS (1999b). Een helder recept: Bevindingen en adviezen van de Begeleidingscommissie Uitvoering Geneesmiddelenbeleid. The Hague: Ministerie van Volksgezondheid, Welzijn en Sport.

Moore, T. G. (1961). The purpose of licensing. Journal of Law and Economics, 4, 93-117.

Nelson, P. (1970). Information and consumer behavior. Journal of Political Economy, $78,311-329$.

Nys, H. (1981-1982). De nieuwe criteria voor de vestiging van apotheken. Rechtskundig Weekblad, 45, 2567-2576.

Ogus, A. I. (1994). Regulation: Legal form and economic theory. Oxford: Clarendon Press.

Olson, M. (1965). The logic of collective action: Public goods and the theory of groups. Cambridge, MA: Harvard University Press.

Peltzman, S. (1976). Toward a more general theory of regulation. Journal of Law and Economics, 19, 211-240.

Posner, R. A. (1974). Theories of economic regulation. Bell Journal of Economics and Management Science, 5, 335-358.

PriceWaterhouseCoopers (1999). The Dutch drug expenditure and policy in a European context: A quick scan comparison of the Dutch expenditure on drugs and the underlying policy in several European countries. The Hague: PriceWaterhouseCoopers.

RVZ (1998). Farmaceutische zorg door arts en apotheker. Zoetermeer: Raad voor de Volksgezondheid en Zorg.

SFK (1999). Data en feiten 1999: Kostenontwikkeling van de farmaceutische hulp. The Hague: Stichting Farmaceutische Kengetallen.

SFK (2000). Data en feiten 2000: Kostenontwikkeling van de farmaceutische hulp. The Hague: Stichting Farmaceutische Kengetallen.

Shaked, A. \& Sutton, J. (1981). The self-regulating profession. Review of Economic Studies, 48, 843-862.

Stigler, G. J. (1971). The theory of economic regulation. Bell Journal of Economics and Management Science, 2, 3-21.

Tirole, J (1992). The theory of industrial organization. 5th ed. Cambridge, MA: MIT Press.

Van den Bergh, R. (1993). Self-regulation in the medical and legal professions and 
the European internal market in progress. In: M. Faure, J. Finsinger, J. Siegers, \& R. Van den Bergh (Eds.), Regulation of professions: A law and economics approach to the regulation of attorneys and physicians in the U.S., Belgium, the Netherlands, Germany and the U.K., pp. 21-43. Antwerpen: MAKLU.

Varian, H. R. (1984). Microeconomic analysis. 2nd ed. New York: Norton.

\section{THE AUTHORS}

N. J. Philipsen is a Research Associate and M. G. Faure Academic Director of METRO, the Maastricht European Institute for Transnational Legal Research, Maastricht University, PO Box 616, 6200 MD Maastricht, The Netherlands. Fax: +31 43325 9091; e-mail: Niels.Philipsen@FacBurFDR.Unimaas.nl.

The authors are grateful for useful comments to the participants in the Annual Conference of the European Public Choice Society (Paris, 18-21 April, 2001), where an earlier draft of this paper was presented, as well as to two anonymous referees. Financial support from the Dutch Organization for Scientific Research (NWO), ESRgrant 510-10-502 is gratefully acknowledged. 